\title{
Wetlands In a Changing Climate: Science, Policy and Management
}

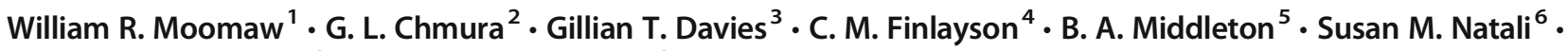 \\ J. E. Perry ${ }^{7} \cdot$ N. Roulet $^{2} \cdot$ Ariana E. Sutton-Grier $^{8}$
}

Received: 5 June 2017 / Accepted: 5 March 2018 / Published online: 5 April 2018

(C) The Author(s) 2018

\begin{abstract}
Part 1 of this review synthesizes recent research on status and climate vulnerability of freshwater and saltwater wetlands, and their contribution to addressing climate change (carbon cycle, adaptation, resilience). Peatlands and vegetated coastal wetlands are among the most carbon rich sinks on the planet sequestering approximately as much carbon as do global forest ecosystems. Estimates of the consequences of rising temperature on current wetland carbon storage and future carbon sequestration potential are summarized. We also demonstrate the need to prevent drying of wetlands and thawing of permafrost by disturbances and rising temperatures to protect wetland carbon stores and climate adaptation/resiliency ecosystem services. Preventing further wetland loss is found to be important in limiting future emissions to meet climate goals, but is seldom considered. In Part 2, the paper explores the policy and management realm from international to national, subnational and local levels to identify strategies and policies reflecting an integrated understanding of both wetland and climate change science. Specific recommendations are made to capture synergies between wetlands and carbon cycle management, adaptation and resiliency to further enable researchers, policy makers and practitioners to protect wetland carbon and climate adaptation/resiliency ecosystem services.
\end{abstract}

Keywords Carbon in wetlands · GlobalCarbon cycle $\cdot$ Carbon sink and sources $\cdot$ Inland wetlands carbon $\cdot$ Coastal wetland carbon · Peatland carbon $\cdot$ Permafrost $\cdot$ Climate resiliency $\cdot$ Climate adaptation $\cdot$ Wetlands and climate policy $\cdot$ Coastal wetlands $\cdot$ Northern peatlands · Climate impacts on wetlands · Greenhouse gasses and wetlands · Wetland soils · Wetland restoration · Wetland conservation $\cdot$ Wetland protection $\cdot$ Climate change

William R. Moomaw

william.moomaw@tufts.edu

G. L. Chmura

gail.chmura@mcgill.ca

Gillian T. Davies

gdavies@bscgroup.com

C. M. Finlayson

mfinlayson@csu.edu.au

B. A. Middleton

middletonb@usgs.gov

Susan M. Natali

snatali@whrc.org

J. E. Perry

jperry@vims.edu

N. Roulet

nigel.roulet@mcgill.ca

Ariana E. Sutton-Grier

ariana.suttongrier@gmail.com
1 Center for International Environment and Resource Policy. The Fletcher School of Law and Diplomacy and Global Development and Environment Institute, Tufts University, Medford, MA 02155, USA

2 Department of Geography, McGill University, 805 Sherbrooke St W, Montreal, QC H3A 0B9, Canada

3 BSC Group, Inc., 33 Waldo Street, Worcester, MA 01608, USA

4 Institute for Land, Water, and Society, Charles Sturt University, Albury, NSW 2640, Australia

5 U.S. Geological Survey, Wetlands and Aquatic Research Center, Lafayette, LA 70506, USA

6 Woods Hole Research Center, Falmouth, MA 02540, USA

7 Virginia Institute of Marine Science, College of William and Mary, PO Box 1346, Gloucester point, VA 23062, USA

8 Earth System Science Interdisciplinary Center, University of Maryland USA and the MD/DC Chapter of the Nature Conservancy, Bethesda, MD, USA 


\section{Introduction}

The Millennium Ecosystem Assessment (2005) identifies climate regulation as one of the most significant ecosystem services provided by wetlands, and also identifies their role in buffering the effects of climate change (thereby supporting climate adaptation and resiliency), as well as many additional ecosystem services. Wetlands sequester some of the largest stores of carbon on the planet, but when disturbed or warmed, they release the three major heat-trapping greenhouse gases (GHGs), carbon dioxide $\left(\mathrm{CO}_{2}\right)$, methane $\left(\mathrm{CH}_{4}\right)$ and nitrous oxide $\left(\mathrm{N}_{2} \mathrm{O}\right)$. Rising planetary temperatures are causing a positive feedback from warming wetlands and thawing permafrost that is accelerating global warming. By 2015 increased concentrations of greenhouse gases in the atmosphere have raised the global average temperature by approximately $1^{\circ} \mathrm{C}$ above preindustrial values (Hawkins et al. 2017). Further warming is expected to add $130-160 \mathrm{Pg}$ (1 Petagram is $10^{15}$ grams) of permafrost carbon (C) to the atmosphere by 2100 (Schuur et al. 2015). To place this in perspective, that amount of $\mathrm{C}$ is comparable to continuing current annual United States fossil fuel emissions until the end of the century (Friedlingstein et al. 2014, USEPA 2017).

Protecting all types of wetland ecosystems from direct human disturbance, minimizing additional warming by reducing GHG emissions from all sources, and increasing terrestrial $\mathrm{CO}_{2}$ sinks to remove atmospheric $\mathrm{CO}_{2}$ are major priorities for limiting future temperature increases.

In Part 1 of this paper, we provide a comprehensive review of the consequences of climate change for saltwater and freshwater wetlands. Freshwater wetlands include a variety of cover types characterized by herbaceous plants, shrubs and/or trees. Some freshwater wetlands are underlain by permafrost (soil temperature $<0^{\circ} \mathrm{C}$ for two or more years). In this paper, saltwater wetlands refer to tidal coastal wetlands that include salt marshes, mangroves and seagrass meadows. We also examine the important and often-neglected role that wetlands play in actively removing $\mathrm{CO}_{2}$ from the atmosphere and sequestering $\mathrm{C}$ in wetland soils over long time periods, the potential for expanding that role and the important climate adaptation and resiliency ecosystem services that wetlands provide. For the purposes of this paper, resiliency is defined as the ability for an ecosystem to restore healthy ecological function, complexity, diversity and processes following a disruption, although specific species and species assemblages may change.

In Part 2 of this paper, we identify international, national, sub-national and local wetlands policies and explain their implications for addressing climate change. We note that often the role of wetlands in climate treaties and policies is only by inference. We conclude by describing how climate scientists, wetland scientists, policy makers and wetland practitioners can manage and conserve wetlands in light of climate change.

\section{Part 1: Wetlands In a Changing Climate: The Science}

The United Nations Framework Convention on Climate Change calls for the "stabilization of greenhouse gas concentrations in the atmosphere at a level that would prevent dangerous anthropogenic interference with the climate system" (UNFCCC 1992). The Paris Climate Agreement in 2015 (UNFCCC 2017) established a goal of keeping global average temperature increase substantially less than $2^{\circ} \mathrm{C}$ above the preindustrial value, and making every attempt to keep it below $1.5^{\circ} \mathrm{C}$.

In order to have a two in three probability of keeping global average temperature from rising by more than $2^{\circ} \mathrm{C}$, it is essential to have "negative emissions" of GHGs; in other words, meeting the goal of the Paris Climate Agreement requires active removal and sequestration of atmospheric $\mathrm{C}$ (Sanderson et al. 2016). Sequestration is used here to refer to the photosynthetic removal of $\mathrm{CO}_{2}$ from the atmosphere and its conversion into cellulose and other carbon compounds in plants, and its conversion from decaying plants into soil organic matter. Ricke and Caldeira (2014) have shown that peak warming occurs within about one decade after a pulse of $\mathrm{CO}_{2}$ is added to the atmosphere. Hence the benefits of avoided $\mathrm{CO}_{2}$ emissions will be manifested within the lifetimes of people who acted to avoid those emissions. Solomon et al. (2009) have shown that after peak warming is reached, effects will persist for 1000 years. IPCC estimates that depending upon the scenario, "about 15 to $40 \%$ of $\mathrm{CO}_{2}$ emitted by 2100 will remain in the atmosphere longer than 1000 years" (Ciais et al. 2013) affecting 40 generations. Hence avoiding emissions of GHGs to the atmosphere is recommended to be a prime consideration that benefits both present and future generations.

For most types of wetlands, the bulk of sequestered carbon is in the soils rather than in the plant communities. Draining these wetlands to convert them to agriculture as has been done in many countries and regions including Indonesia, Malaysia, Russia, New Zealand, Florida Everglades and in Northern Europe, allows soil organic matter to be oxidized and release $\mathrm{CO}_{2}$ into the atmosphere. When mangroves are removed for coastal development and for aquaculture, or forested wetlands are harvested, additional carbon is released from soils and harvest residues. In the Southeast United States, a major wood pellet fuel industry has developed where the carbon in the wood is released as $\mathrm{CO}_{2}$ immediately upon combustion. The use of wood pellets to replace coal for electricity, on the mistaken assumption that it is carbon neutral, is expected to grow substantially by 2050 (IEA 2017), further degrading forested wetlands while adding large amounts of $\mathrm{CO}_{2}$ to the atmosphere.

$\mathrm{CO}_{2}$, added to the atmosphere by human activity, is the primary GHG responsible for climate change, followed by $\mathrm{CH}_{4}$ and $\mathrm{N}_{2} \mathrm{O}$ (Myhre et al 2014). These gases move among 
the natural reservoirs of terrestrial and marine plants, soils, oceans and the atmosphere. Human activity has reduced the size and capacity of these reservoirs while increasing GHG emissions (Ciais et al. 2013). Altering albedo (solar reflectivity from the earth's surfaces) from land use change can increase or decrease global warming. Climate forcing (heat trapping) from black $\mathrm{C}$ (particulate matter from fossil fuel and biofuels combustion (Bond et al. 2013) is a significant contributor to global warming.

The average annual anthropogenic $\mathrm{CO}_{2}$ emissions for the period 2006-2015 are estimated to be $10.3 \mathrm{PgCy}^{-1}$ (Petagrams $\mathrm{C}$ per year or $10^{15}$ grams $\mathrm{C}$ per year) with 9.3 $\pm 0.5 \mathrm{PgCy}^{-1}$ from fossil fuels and industrial processes and $1.0 \pm 0.5 \mathrm{PgCy}^{-1}$ from land use change (Fig. 1, Le Quéré et al. 2016). The total $\mathrm{CO}_{2}$ emissions from fossil fuels and industrial processes between 1750 and 2011 are estimated to be $375 \pm 30 \mathrm{PgC}$, and the total amount from land use change is estimated to be $180 \pm 80 \mathrm{PgC}$. Therefore, nearly one-third of $\mathrm{CO}_{2}$ added to the atmosphere from human activity has come from deforestation and oxidation of disturbed soil organic matter (Ciais et al. 2013). By November 2017, $\mathrm{CO}_{2}$ in the atmosphere had increased to $865 \mathrm{PgC}$ or $406 \mathrm{ppm}$ (NOAA 2018).
The net annual increase of $\mathrm{CO}_{2}$ in the atmosphere each year is $4.5 \pm 0.5 \mathrm{PgCy}^{-1}$ or slightly less than half of annual emissions, and concentrations have increased by over $40 \%$ above preindustrial levels. The biosphere has been the major means for removing and sequestering atmospheric $\mathrm{CO}_{2}$ for over 300 million years, but its potential to be a major resource for addressing climate change has been underappreciated in current policy discussions. Each year, $2.6 \pm 0.5 \mathrm{PgC}$ equal to about $25 \%$ of annual emissions is removed by the ocean's phytoplankton or is dissolved in the ocean's waters. The difference between total emissions to the atmosphere and net removals by the oceans requires that an additional amount of $\mathrm{CO}_{2}$ equivalent to $3.1 \pm 0.9 \mathrm{PgCy}^{-1}$ would need to be removed by terrestrial ecosystems to balance the carbon flows. This is nearly $30 \%$ of annual anthropogenic emissions from all sources. This analysis only reports estimates of the aggregate removal of $\mathrm{CO}_{2}$ by the terrestrial biosphere (all plants and soils), and does not explicitly consider the specific role of wetlands as either a source or a sink (Fig. 1, Le Quéré et al. 2016).

$\mathrm{CH}_{4}$ has a 100-year Global Warming Potential more than 28 times that of $\mathrm{CO}_{2}$ (Myhre et al. 2013). It is estimated that between 1750 and 2011 human activity has increased
Fig. 1 Global carbon dioxide budget (Le Quéré et al. 2016). Note that approximately $10 \%$ of annual emissions are from land use change, and that the land sink removes an amount equal to about $33 \%$ of annual emissions. This value is calculated by difference, and wetlands are not counted separately from the total land sink. 1 Gigatonne ( $10^{9}$ tonnes) equals 1 Petagram $\left(10^{15)}\right.$ grams

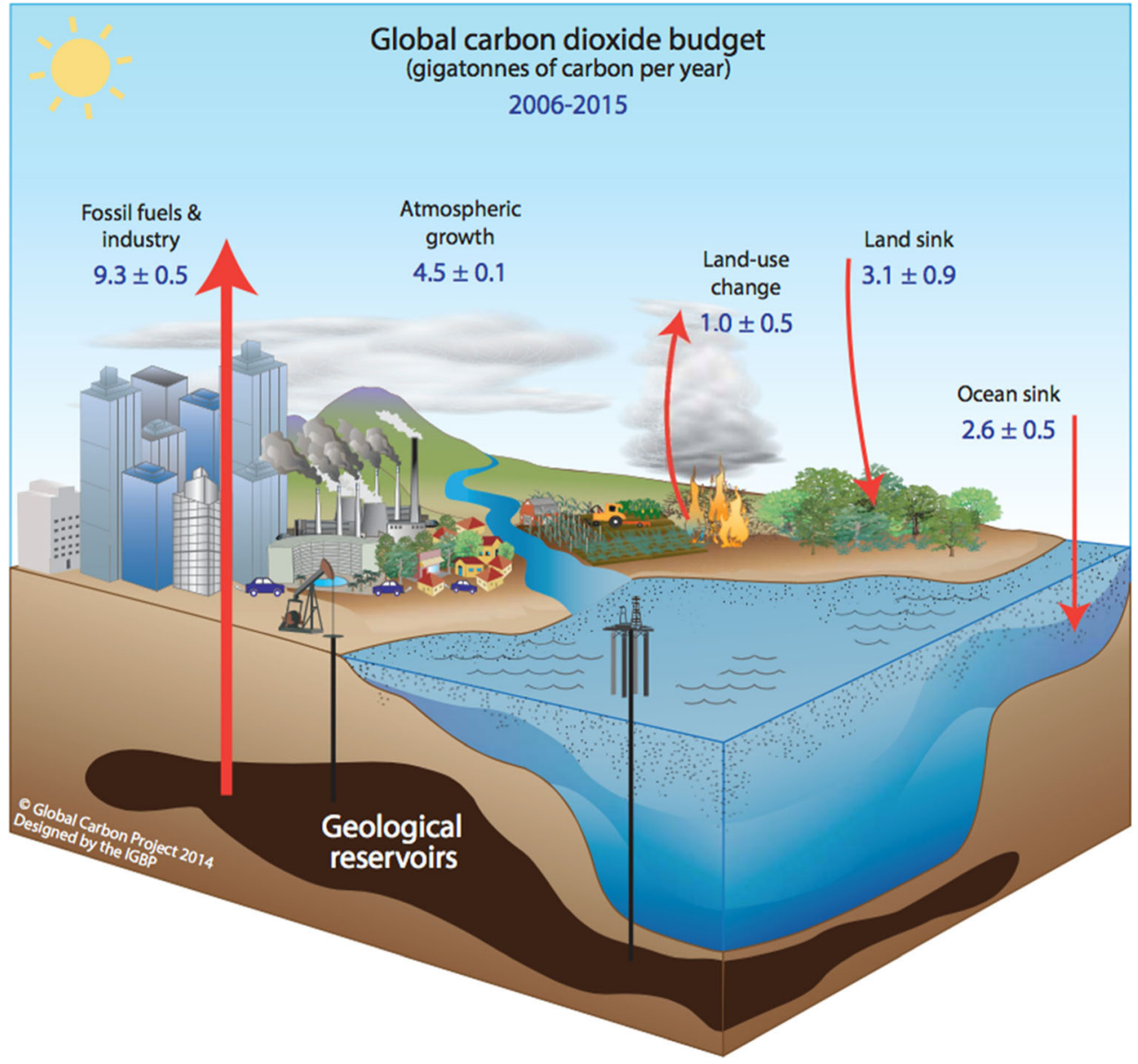


atmospheric $\mathrm{CH}_{4}$ by a factor of 2.5 from 1984 to $4954 \mathrm{Tg} \mathrm{CH}_{4}$ $\mathrm{y}^{-1}$ (722 ppb to1803 ppb) (1 Teragram $\mathrm{CH}_{4}$ is $10^{12}$ grams $\mathrm{CH}_{4}$ ) (Ciais et al. 2013). Currently the major sources of emissions arise from fossil fuel usage $\left(85-105 \mathrm{Tg} \mathrm{CH}_{4} \mathrm{y}^{-1}\right)$, ruminant livestock (87-94 $\mathrm{Tg} \mathrm{CH}_{4} \mathrm{y}^{-1}$ ), landfills and waste (67-90 $\mathrm{Tg} \mathrm{CH}_{4} \mathrm{y}^{-1}$ ), and rice production (33-40 $\mathrm{Tg} \mathrm{CH}_{4} \mathrm{y}^{-1}$ ). Average annual anthropogenic emissions of $\mathrm{CH}_{4}$ from all these sources between 2000 and 2009 total between 272-329 $\mathrm{Tg} \mathrm{CH}_{4} \mathrm{y}^{-1}$ $\mathrm{CH}_{4}$ is removed from the atmosphere at a rate of $492-785 \mathrm{Tg}$ $\mathrm{CH}_{4} \mathrm{y}^{-1}$ mostly by atmospheric chemistry with small contributions from soil oxidation (Fig. 2) (Ciais et al. 2013). $\mathrm{CH}_{4}$ emissions from wetlands are between 177 and $284 \mathrm{Tg} \mathrm{CH}_{4} \mathrm{y}^{-1}$, with an additional 8-73 $\mathrm{Tg} \mathrm{CH}_{4} \mathrm{y}^{-1}$ emitted from freshwater sources.

Nitrous oxide $\left(\mathrm{N}_{2} \mathrm{O}\right)$ has a radiative forcing $\sim 300$ times that of $\mathrm{CO}_{2}$. It is a byproduct of both nitrification (under aerobic conditions) and denitrification (under anaerobic conditions), and thus can be produced in wetland soils (Megonigal et al. 2004). However, freshwater and saltwater wetland soils are a source of $\mathrm{N}_{2} \mathrm{O}$ only if they receive excessive levels of reactive nitrogen - otherwise they may be a sink for this potent GHG (e.g. Auget et al 2014, Chmura et al. 2016).

While natural solutions have focused on the role of forests to remove and sequester $\mathrm{CO}_{2}$, there is substantially more $\mathrm{C}$ sequestered in soils than in vegetation. The range of estimates for carbon sequestered in vegetation is $450-650 \mathrm{PgC}$, while the estimate for $\mathrm{C}$ stored in soils is $1500-2400 \mathrm{PgC}$ with an additional $1700 \mathrm{PgC}$ estimated to be in permafrost (Ciais et al. 2013). The large amount of carbon sequestered in wetlands is discussed in subsequent sections. As soils warm, and as permafrost thaws, these soils release their stored $\mathrm{C}$ as $\mathrm{CO}_{2}$ or $\mathrm{CH}_{4}$ resulting from microbial decomposition of soil organic carbon (SOC). These feedback emissions trap additional heat and warm the planet further. A first priority is to avoid disturbing wetlands and keep temperatures from rising as much as possible. As the subsequent sections illustrate, wetlands can play a significant role in addressing climate change by sequestering $\mathrm{C}$, and by providing climate resiliency and adaptation while providing additional ecosystem services.

To limit excessive warming, it is necessary to stabilize $\mathrm{CO}_{2}, \mathrm{CH}_{4}, \mathrm{~N}_{2} \mathrm{O}$ and other GHG concentrations in the atmosphere at an appropriate level, by decreasing emission rates and increasing removal rates. There are three basic strategies for accomplishing this goal.

1. Reduce the addition of GHGs into the atmosphere from fossil fuels, biofuels, industry, agriculture and other sources to near zero.

2. Prevent the climate and land-use mediated release of additional GHGs $\left(\mathrm{CO}_{2}, \mathrm{CH}_{4}, \mathrm{~N}_{2} \mathrm{O}\right)$ from wetlands, including wetlands underlain by permafrost, from deforestation
Fig. 2 Global methane $\left(\mathrm{CH}_{4}\right)$ budget (Ciais et al. 2013). Average annual anthropogenic emissions of methane from fossil fuels, ruminants, landfills and waste and rice cultivation between 2000 and 2009 total between 272-329 $\operatorname{Tgy}^{-1}$. For comparison, natural wetlands and freshwaters are estimated to release between 185-357 $\mathrm{Tgy}^{-1}$. $\mathrm{CH}_{4}$ is removed at a rate of 492$785 \mathrm{Tgy}^{-1}$ mostly by atmospheric chemistry with small contributions by soil oxidation. Black arrows represent natural emissions, red arrows represent anthropogenic emissions since 1750 , and the brown arrow represents emissions from both natural fires and anthropogenic biomass burning. 1 Teragram equals $10^{12}$ grams

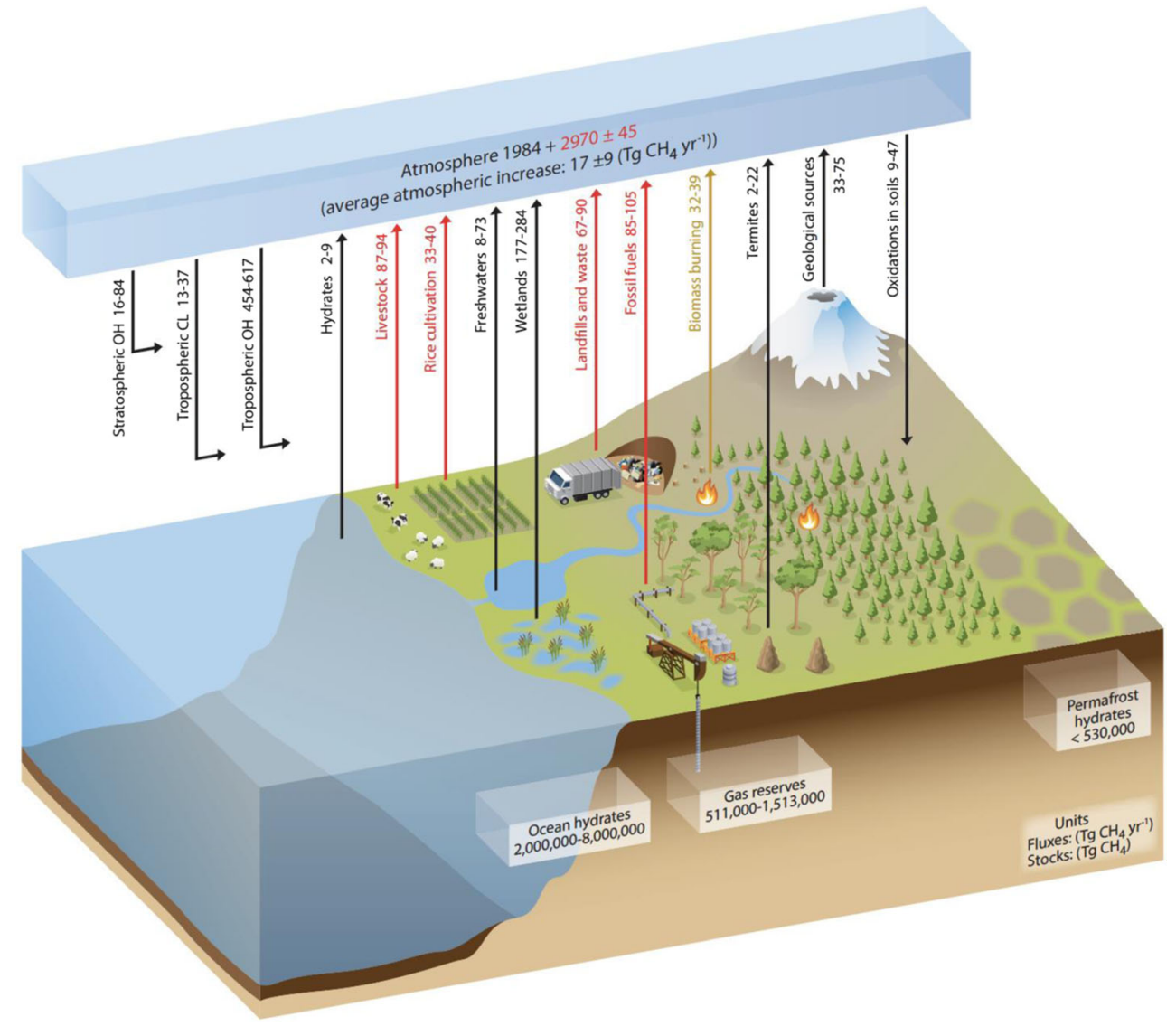


and forest degradation, and from all soils including degraded grassland and agricultural soils.

3. Increase the capacity of natural systems including wetlands to actively remove $\mathrm{CO}_{2}$ from the atmosphere and sequester the $\mathrm{C}$ for the long-term.

\section{Carbon Accumulation and GHG Emissions from Freshwater Wetlands (Including Permafrost) In a Changing Climate}

Wetland conservation has important implications for atmospheric $\mathrm{C}$ cycles, since a substantial portion of the soil $\mathrm{C}$ pool is stored in wetlands. Northern high latitude and tropical peatlands store more than $600 \mathrm{PgC}$ (Gorham 1991; Hugelius et al. 2014), which is among the largest reserves in the world (Köchy et al. 2015). This amount is more than two-thirds as much as is stored in the atmosphere and comparable to the amount stored in global forest biomass (Pan et al. 2011). Wetland conditions are critical for $\mathrm{C}$ accumulation and storage since decomposition in these systems is limited by a lack of oxygen due to water saturation (Brinson et al. 1981). Therefore, when plant productivity exceeds decomposition there is a net accumulation of soil $\mathrm{C}$. This process eventually develops deep peat deposits, which may accumulate for thousands of years. In high latitudes of the Northern Hemisphere, the accumulation process is further intensified by the presence of permafrost, which can have contrasting effects on hydrology, leading to either wetland formation or loss (Sannel and Kuhry 2008). The negative climate feedback (i.e. net cooling effect) that results from increased plant productivity and the longterm $\mathrm{C}$ accumulation and storage by wetlands is, in part, offset by $\mathrm{CH}_{4}$ emissions from freshwater wetlands (Turetsky et al. 2014). Freshwater wetlands represent the largest natural source of $\mathrm{CH}_{4}$, releasing approximately $180-220 \mathrm{Pg} \mathrm{CH}_{4} \mathrm{yr}^{-1}$ (Mikaloff Fletcher et al. 2004, Kirschke et al. 2013). However, wetlands that accumulate peat account for less than a quarter of all wetland $\mathrm{CH}_{4}$ emissions (Turetsky et al. 2014 and references therein).

The influence of future climate on wetland soils $\mathrm{C}$ will depend upon the same factors that facilitated $\mathrm{C}$ accumulation in these systems: water saturated soils and minimal modification of wetlands through land-use change, and in the case of high latitude peatlands, low temperature. Globally, temperature, low oxygen (due to soil saturation), and the chemical and physical form of the organic matter, are the primary factors limiting decomposition in wetlands. Changes in precipitation and evapotranspiration patterns, which alter the water balance of wetland ecosystems, will substantially influence wetland $\mathrm{C}$ cycling. However, the magnitude, directionality, and seasonality of projected hydrologic changes are regionally variable (Collins et al. 2013), and therefore, the fate of soil $\mathrm{C}$ stored in wetlands will depend on local conditions. In contrast, changes in the global energy balance, usually manifested by an increase in temperature, are most likely to accelerate the decomposition rate of wetland organic $\mathrm{C}$ stored at the soil surface. Deeper C pools may be unaffected unless there are associated changes in hydrology (van Groenigen et al 2016). These potential losses of belowground $\mathrm{C}$ may also be partially offset by increased primary productivity.

The greenhouse gas dynamics of permafrost regions differ in important ways from liquid water wetlands. The microbial metabolism of soil carbon is greatly reduced when the soils are frozen for long periods. Thawing changes the availability of oxygen and liquid water, and activates bacterial metabolism, which leads to a relatively abrupt increase in emissions of either or both carbon dioxide and methane. In addition, the low solubility of methane in water causes the accumulation of this gas in bubbles under the permafrost layer. Thawing releases these bubbles, which substantially contributes to this abrupt emission increase. In permafrost regions, increased temperature will have both direct and indirect effects on wetland $\mathrm{C}$ storage; permafrost thaw can dramatically affect hydrology in the Arctic, but the $\mathrm{C}$ consequences of that change are dependent upon landscape conditions (Olefeldt et al. 2016). Permafrost thaw can lead to wetland drainage because permafrost restricts vertical water flow. As the permafrost thaws to deeper soil layers or is completely thawed, the perched water table may be lowered, resulting in drier surface soils. Permafrost-mediated wetland drainage can lead to substantial $\mathrm{C}$ losses because of higher rates of aerobic bacterial metabolism. However, permafrost thaw can also result in ground collapse that can cause wetland formation and substantially increase $\mathrm{CH}_{4}$ emissions from permafrost ecosystems (Christensen et al. 2004; Natali et al. 2015; Schuur et al. 2015).

The effects of climate changes on wetland $C$ storage will be determined largely by the extent to which the wetlands have been modified through land-use change (Petrescu. et al 2015). Altering wetlands can increase the vulnerability of the organic $\mathrm{C}$ pool by weakening the self-regulating feedbacks that exist in many peatland systems (Frolking et al. 2010). Land use change that affects wetland hydrology has had substantial impacts on wetland structure and function. Draining wetlands decreases $\mathrm{CO}_{2}$ uptake and increases rates of microbial decomposition and $\mathrm{CO}_{2}$ release (Mietten et al 2017). Soil C is also lost by peat extraction, drainage and other disturbance (Laine et al. 2014; Evans et al. 2015; Page and Baird 2016). The hydrologic changes can be so large that they result in massive losses of $\mathrm{C}$ to the atmosphere, such as occurred during the fires in tropical peatlands in Southeast Asia (Page et al. 2002).

While the drainage of natural wetlands for conversion to agricultural land results in net losses of soil organic $\mathrm{C}$, radiative forcing from wetland conversion depends on relative changes in the direction and magnitude of two major GHGs: $\mathrm{CO}_{2}$ and $\mathrm{CH}_{4}$ (Petrescu et al. 2015). Despite a decline in $\mathrm{CH}_{4}$ emissions following wetland drainage, wetland conversion to cropland results in a significant net increase in atmospheric radiative forcing (heat trapping) (Petrescu et al. 2015). On the other hand, land use changes that cause flooding and creation of wetlands can alter $\mathrm{C}$ pools through the saturation and burial 
of organic C (Knoll et al. 2014). Despite the potential for C sequestration, reservoir formation leads to increased GHG emissions, primarily because of $\mathrm{CH}_{4}$ emissions from ponded water and highly fluctuating water levels in reservoirs compared to natural lakes (Deemer et al. 2016; Hayes et al. 2017).

Increased atmospheric $\mathrm{CO}_{2}$ is projected to almost double current freshwater wetland $\mathrm{CH}_{4}$ emissions, primarily due to warmer temperatures as well as enhanced precipitation (Shindell et al. 2004). The increase in $\mathrm{CH}_{4}$ emissions under high $\mathrm{CO}_{2}$ concentrations will primarily result from increased emission rates from tropical wetlands and from wetland expansion in northern high latitudes (Shindell et al. 2004; van Groenigen et al. 2011). The response of wetlands to future climate scenarios will also vary across wetland systems. For example, Wu and Roulet (2014) suggest that ombrotrophic (rain-fed) peatlands will maintain structure and function, but fen-like systems that rely on terrestrial water inputs are much more vulnerable to climate change. Land use and climatemediated changes in $\mathrm{CH}_{4}$ emissions from freshwater wetlands can produce a large increase in radiative forcing (heat trapping) in decades to several centuries, but in the long-term (century-millennia), C sequestration by wetlands represents, at present, a net cooling effect (Frolking and Roulet 2007; Neubauer and Megonigal 2015). However, land use, land use change, and fire can cause abrupt changes in soil C storage in wetlands, switching these long-term $\mathrm{C}$ sinks to sources of C to the atmosphere (Joosten et al. 2016).

\section{Ecological Consequences for Freshwater Wetlands in a Changing Climate}

Freshwater wetlands may be altered by climate change in all geographic regions of the world (Junk et al. 2013). A changed climate will alter hydrology, and functionality may be impaired by increased temperatures, drought or flooding events, $\mathrm{CO}_{2}$ increases, and/or salinity intrusion (Junk et al. 2013). These changes will affect critical functions and ecosystem services such as carbon storage, biodiversity support, wildlife habitat and water quality (Junk et al. 2013). Negative impacts related to climate change will be compounded by synergies with other stressors, such as invasive species and land use change, thereby potentially increasing both the difficulties in managing and restoring wetlands, and the risk of endemic species extinctions (Erwin 2009).

Despite these challenges, some freshwater wetlands may be relatively resilient to climate change (Baron et al. 2002; Middleton and Souter 2016) within certain boundaries of temperature, precipitation, water level, salinity intrusion, and storm activity (Poff et al. 2002; Bernstein et al. 2007). At the same time, salinity intrusion poses specific threats to coastal freshwater wetlands because many species in these ecosystems are intolerant of salinity (Keddy 2010). Also, these species often have lower levels of production if salinity levels become too high (Middleton 1999;
Sutter et al. 2014; Middleton and Souter 2016). A recent review synthesizes the state of our knowledge on how salinization associated with climate change will impact these wetlands (Herbert et al. 2015).

Climate change poses threats to non-coastal freshwater wetlands as well; hydrology is shifting as many local water regimes have become wetter or drier in recent decades (Fig. 3) (Mallakpour and Villarini 2015). In particular, megadroughts predicted by climate models (Cook et al. 2015) may dry Midwestern and Southwestern wetlands in North America with severe consequences for both wetlands and society. Severe droughts could impair the ability of these wetlands to maintain services including water quality, water supply, flood control, storm protection, and direct harvests of fish, animals, and plants, ultimately with severe negative impacts on ecosystem function and biodiversity (Baron et al. 2002; Middleton and Souter 2016). In addition, reduced winter snowpack and earlier snowmelt are impacting northern freshwater wetlands by altering the timing and magnitude of stream flows (Lawler 2009). In northern areas with permafrost, vegetation structure completely changes after permafrost melts (Malhotra and Roulet 2015). In fact, climate change is already changing community composition, species distribution, phenology, physiology and invasive species presence (Lawler 2009).

Unfortunately, many of the world's freshwater wetlands are already stressed by increased land-use pressure, so that additional hydrological alteration can contribute to an overall decrease in resilience to climate change (Baron 2002; Middleton and Souter 2016). Human alteration is commonplace throughout river corridors, challenging management as the impacts of upstream alterations accumulate along the waterway (See Fig. 4). (DuBowy 2013; Tockner and Stanford 2002). As demands for river resources increase, such problems are expected to worsen (Baron et al. 2002). Flowing water is compromised by river re-engineering practices, even though moving water generally improves oxygenation and plant health (Middleton 1999). Also, upriver freshwater extraction in tidal freshwater wetlands coupled with sea level rise can cause the salinification of surface and ground water, with accompanying stress and even the collapse of tidal vegetation in the freshwater reaches of estuaries (Perry and Atkinson 2009; Middleton and Souter 2016).

Fortunately, emerging research suggests that vegetation collapse sometimes can be avoided by hydrologic remediation (Souter et al. 2010). Freshwater remediation can reduce salinity and revive freshwater forests stressed by salinity intrusion, if the vegetation is not fatally damaged (Middleton et al. 2015; Middleton and Souter 2016). Such techniques could become critical for maintaining future ecosystem health and services (Baron et al. 2002; Middleton and Souter 2016). To date, there is no report of long-term monitoring of the survival of vegetation following remediation, so any long-term benefits are untested (Middleton and Souter 2016). Managers may need to carefully monitor the effects of traditional techniques and 
Fig. 3 The magnitude and frequency of flood events in the Midwestern United States from 1962-2011. Triangles show trends of flooding at U.S.G.S. gage stations with trends (positive, negative, neutral; blue triangle, red triangle, and gray circle, respectively; from Mallakpour and Villarini 2015)

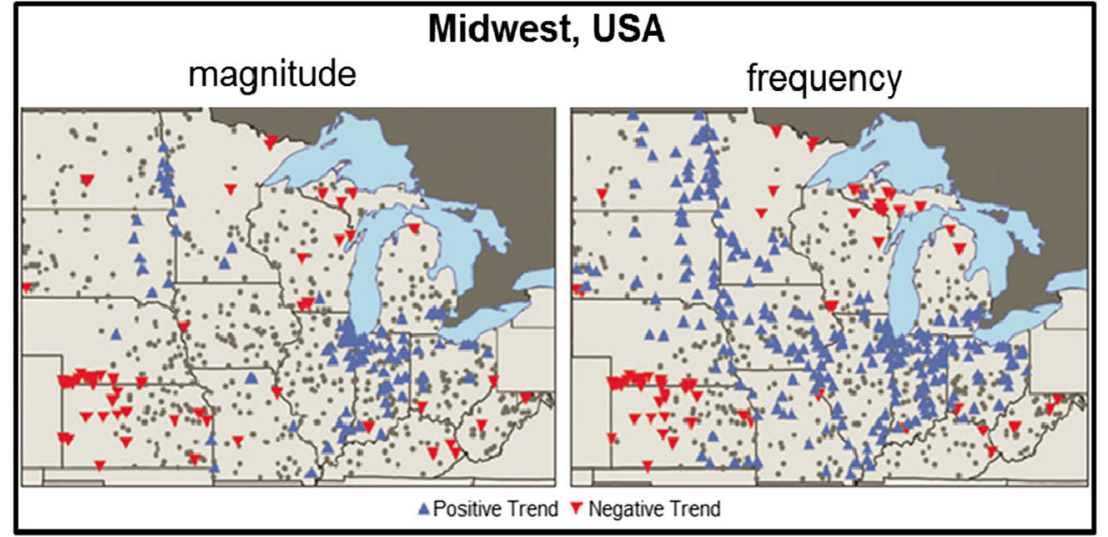

adjust the timing and/or intensity of management actions accordingly (Jackson and Hobbs 2009; Middleton et al. 2017).

One harbinger of ecosystem change is that the early life history stages of foundation species (species with a strong role in structuring communities) are increasingly unsuccessful at the hot or dry edges of their ranges, noting that juveniles are more sensitive to environmental extremes than adult plants (Jackson and Hobbs 2009). Without regeneration, vegetation enters a relict state (Williams et al. 1999). Worldwide examples of relict foundation species are growing, and such vegetation may be poised for abrupt decline if disturbance removes adult vegetation (Middleton et al. 2017). There are several indicators that some freshwater wetlands are poised for collapse at the edges of their ranges, and the loss of all but relict species is a key indicator of that problem (Middleton et al 2017). Thus, freshwater wetlands face a myriad of challenges in the face of climate change.

\section{Salt Marsh and Mangrove Response to a Changing Climate and Associated Sea Level Rise}

Saltwater coastal wetlands are generally found in sheltered waters and include mangrove forests, seagrass meadows, and tidal salt marshes. These wetlands host incredibly productive plant communities, which take up substantial amounts of $\mathrm{C}$ via photosynthesis, and store a significant fraction of that $\mathrm{C}$ in their wet, anaerobic soils (Chmura et al. 2003; Donato et al. 2011; Fourqurean et al. 2012). This $\mathrm{C}$ has been termed "coastal wetland blue carbon." These vegetated saltwater coastal ecosystems represent an estimated $0.2 \%$ of the area of the ocean, but have $\mathrm{C}$ stocks equivalent to $50 \%$ of the $\mathrm{C}$ buried in ocean sediments (Duarte et al. 2013). As such, saltwater coastal blue C wetlands are some of the most $\mathrm{C}$ rich ecosystems on the planet (See Fig. 3 McLeod et al. 2011). Thus, there are growing efforts to include saltwater wetlands in international climate protection activities and policy frameworks (Wylie et al. 2016; Howard et al. 2017).

Salt marshes and mangrove swamps have accumulated Crich soil for centuries to millennia as sea levels have slowly risen increasing levels of plant production (See Fig. 3 in
McLeod et al. 2011). These wetland soils accumulate vertically through three synergistic processes (See Fig. 7 in Fitzgerald et al. 2008). The belowground growth adds volume to the soil and the aboveground portion helps trap inorganic sediment carried in tidal waters that regularly flood the soil. Extended saturation of the soil reduces the rate of decomposition of soil organic matter, thereby enabling the persistence of the effective blue $\mathrm{C}$ sink. Increasing soil volume results in raised surface elevation of the wetland, so that on decadal scales its elevation roughly tracks sea level rise (e.g. Chmura et al. 2001; Ellison 2008). This increase in elevation is accompanied by lateral expansion of the marsh or mangrove swamp over tidal flats in the lower intertidal zone and inland over adjacent terrestrial ecosystems. The vegetation that occupies intertidal niches has evolved a suite of mechanisms to tolerate flooding by saline water, but at a greater expenditure of energy (e.g. Mendelssohn et al. 1982). There is a limit to this tolerance.

Saltwater wetlands provide significant ecosystem services. Mangroves and salt marshes help to slow and attenuate waves and storm surge, reducing the flooding and erosion of ocean coastal communities (Shepard et al. 2011; Arkema et al. 2013). One study suggests that U.S. marine saltwater wetlands provide $\$ 23.2$ billion dollars of storm protection every year (Costanza et al. 2008) while another study estimates that every hectare of salt marsh provides US $\$ 8,234$ dollars, or US $\$ 3,334$ per acre, in storm protection, on average, per year (Barbier et al. 2011). Since a warmer climate contributes to increased storm intensity (Trenberth et al. 2015), enhancing these protective measures is seen as a cost-effective way to protect coastal communities and infrastructure. The storm protection qualities of wetlands are leading many policy and decision makers to consider more investments in protecting or restoring coastal wetlands and other ecosystems to provide the climate adaptation benefits of natural storm and erosion reduction (Barbier 2014; Sutton-Grier et al. 2015).

The impact of climate warming, its associated sea level rise and changes in precipitation patterns will vary considerably within and among tidal marshes. Few studies have looked at combined effects of sea level rise and other aspects of climate 


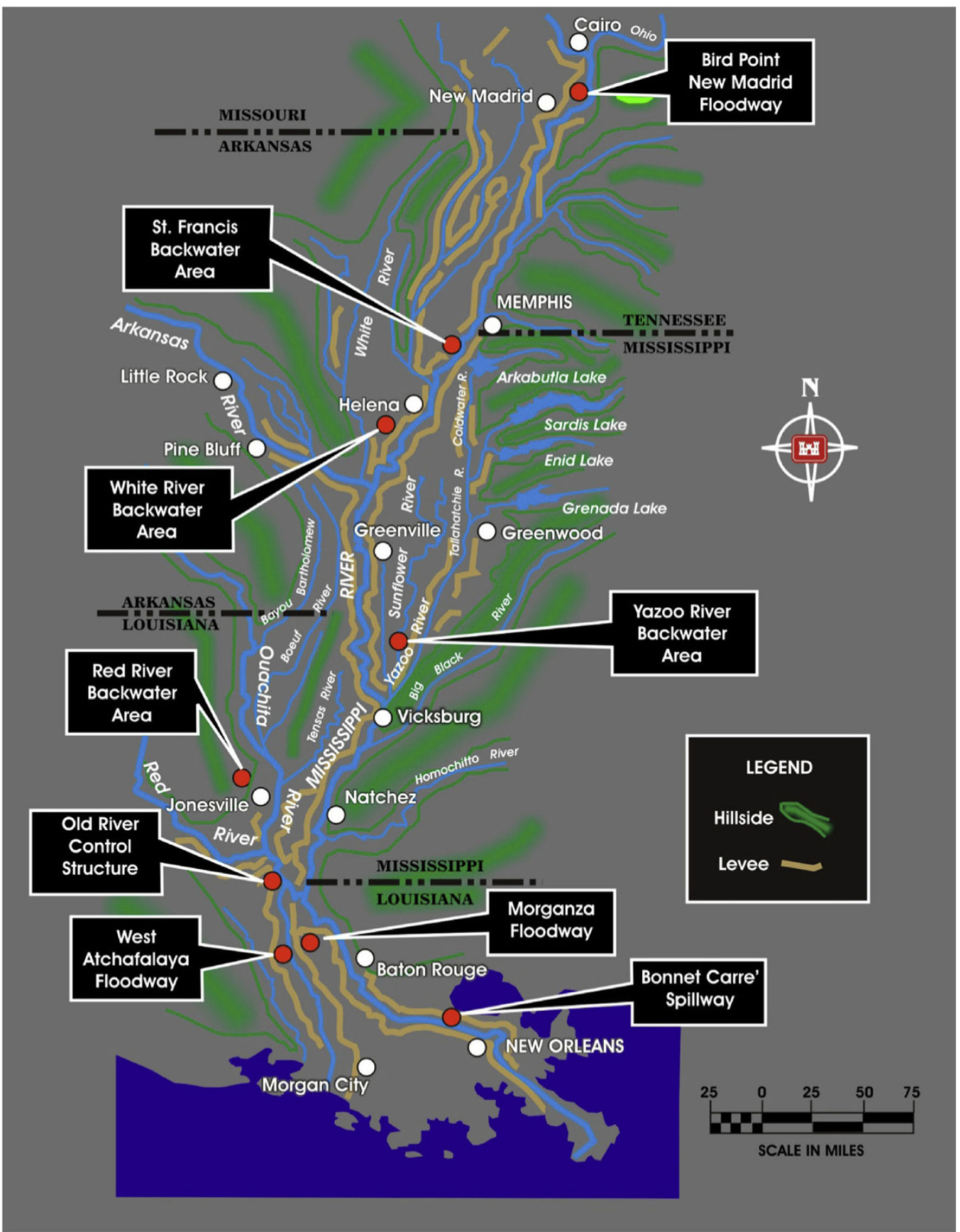

Fig. 4 The hydrologic changes in the Mississippi River and tributaries for navigation and development include straightening, deepening, levee construction and damming. These engineering practices influence

change. Feher et al. (2017) reviewed the literature on the influence of changing temperature and precipitation regimes on tidal saline wetlands. They found that for several ecosystem properties and many regions there was still insufficient evidence to make generalized predictions. ecosystem processes across the floodplain and channel of this big river system (DuBowy 2013)

Research, however, has demonstrated differences due to climate zones and vegetation. For instance, where growing seasons are limited by cold temperatures, such as the coast of the northern Northwest Atlantic, studies have shown that a warmer climate would marginally increase decomposition, 
but will increase plant production and soil carbon storage (Charles and Dukes 2009; Gedan and Bertness 2010; Kirwan et al. 2014), although the effect of a rise of sea level was not addressed. On the Mediterranean coast, experimentally increased temperature, decreased precipitation and increased inundation period caused vegetation to shift from a perennial grass to an annual succulent (Strain et al. 2017).

There are two major ways that climate change is expected to impact all saltwater wetlands. Climate warming is expected to increase rates of sea level rise, resulting in loss of wetland area through "coastal squeeze," particularly in areas surrounded by urbanized uplands (e.g. Torio and Chmura 2013). This has been identified as the largest climate change threat for mangroves (Gilman et al. 2008). Secondly, warmer temperatures will allow poleward shifts in flora and fauna that can result in significant changes in the saltwater tidal habitat, thereby altering its ecosystem services, including ability to store blue $\mathrm{C}$, and in some cases causing the release of $\mathrm{CO}_{2}$ from the blue $\mathrm{C}$ sink as described below.

Modification of estuarine hydrology or increased rates of sea level rise can increase the hydroperiod (duration of flooding) beyond the thresholds tolerated by intertidal vegetation. Climate warming will increase rates of sea level rise primarily from continued melting of the world's ice sheets and glaciers and the thermal expansion of a warming ocean (Church et al. 2013). As the magnitude and rate of ice sheet melting is difficult to model, predicted rates of sea level rise vary, but it is accepted that increasing rates of sea level rise and its impact will be felt on all coastlines, most severely on those already subject to sub-

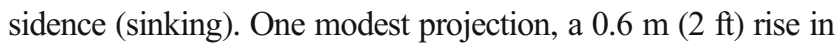
global (eustatic) sea level by 2100 , would translate to an increase of $0.61 \mathrm{~m}(2.3 \mathrm{ft})$ at New York City and $1.07 \mathrm{~m}(3.5 \mathrm{ft})$ in Galveston Texas. The greatest uncertainty is the rate of melting of ice sheets covering Antarctica and Greenland. There is nothing magical about the year 2100 , and it is certain that sea levels will continue to rise for centuries under all current scenarios. A recent report considers six possible outcomes for global mean sea level rise by 2100 ranging from 0.3 meters with a $100 \%$ probability to an intermediate projection of $1.0 \mathrm{~m}$ with a $17 \%$ probability. If recent estimates for Antarctica ice melt are included there is a $0.1 \%$ probability that the rise could reach 2.5 m (NOAA 2017). See Fig. 5.
Within tidal wetlands the effects of increased rates of sea level rise will be most strongly felt at the lower elevations where vegetation will most rapidly succumb and soil accretion will cease (e.g. Kirwan et al. 2010). Without living vegetation, the submerged wetland soil and its $\mathrm{C}$ stock can be exposed to erosion and possibly to oxidation of the organic matter, returning centuries of stored $\mathrm{CO}_{2}$ back to the atmosphere. The fate of soil organic matter eroded from wetlands is an increasingly important science question that is not yet resolved (e.g. DeLaune and White 2012). If the upland adjacent to the tidal wetland is not developed and slopes are gentle, then the wetland can migrate inland, limiting the loss of area (but not necessarily blue carbon stocks). However, if this land is developed or if natural topography is steep, the structures or grade will prevent migration, putting the marsh or mangrove in a coastal squeeze (Torio and Chmura 2013). The potential for coastal squeeze is high on many of the world's coastlines, particularly on the highly urbanized bays and estuaries of the U.S., such as San Francisco Bay in California and the shore of New York City on Jamaica Bay (Hopper and Meixler 2016). The loss of wetland area due to coastal squeeze means loss of all its ecosystem services including essential habitat for fish and wildlife, loss of the ability of the system to store additional $\mathrm{C}$ and loss of its capacity to buffer inland development from the impacts of storms. One opportunity to decrease the amount of salt marsh loss that is likely to occur with sea level rise is to actively plan for future inland marsh migration now. There have been a few innovative studies considering how to plan for marsh migration including one that examined which wetlands along the Gulf coast of the U.S. are most threatened by projected future urban development. This information can be used to identify migration corridors for these wetlands and set priorities for current protection to prevent future coastal squeeze (Enwright et al. 2016). Another study examined two conditions to determine which marshes along the U.S. Northeast and Mid-Atlantic coast are likely to be resilient to sea level rise by examining the current health of the marsh as well as its potential to migrate inland (Anderson and Barnett 2017).

Climate warming has a direct impact on salt marshes and mangrove swamps by increasing poleward migration of their flora and fauna. Such changes are most observable where
Fig. 5 Past and projected changes in global mean sea level rise. (NOAA 2017a). Mean sea level rise and projections to 2100 under alternative IPCC scenarios. The lowest rise is 0.30 meters ( $100 \%$ probability), the intermediate is 1.0 meters $(17 \%$ probability) and the highest is to 2.5 meters $(0.1 \%$ probability)

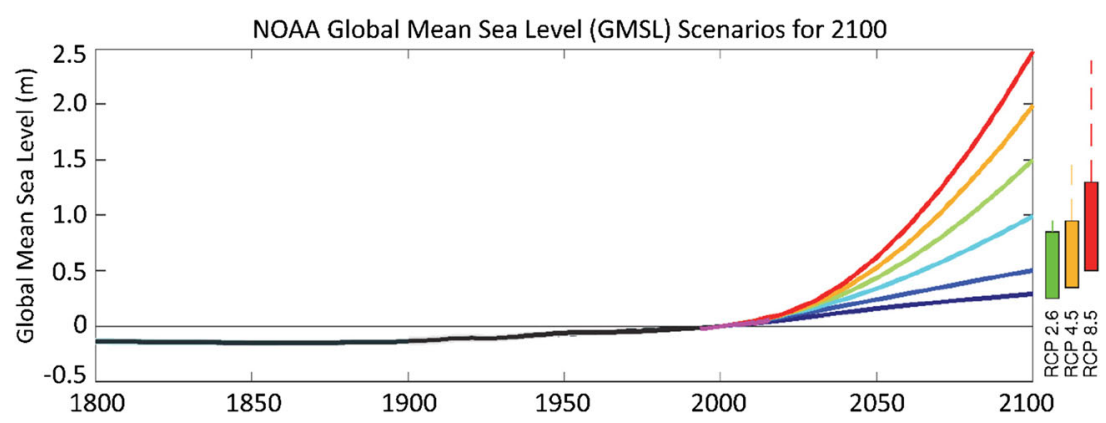


species' populations occur near the edge of their biogeographic ranges. In fact, globally, mangroves are expanding their range from tropical and subtropical climes, to invade salt marshes on adjacent warm temperate coasts (e.g. Godoy and DeLacerda 2015). Studies are finding that climate-changed-induced movement of mangroves into saltmarsh with warming temperatures is resulting in increases in the carbon stored in biomass and soils in marine and estuarine mangroves. This is because mangrove forests have some of the highest average $\mathrm{C}$ storage per land area in unmanaged terrestrial ecosystems (Doughty et al. 2015, Kelleway et al. 2015). As mangroves replace salt marsh vegetation, soil C may increase (Bianchi et al. 2013). However, such invasions significantly change habitat structure and we know little about impacts on biotic interactions, potential lags for co-evolved species to shift, or challenges to mosquito control management (Dale et al. 2013). While SLR is expected to enable mangroves to migrate inland where other obstacles do not occur, the example of mangrove dieback in northern Australia (Duke et al. 2017) shows that the impact of climate is more complex, with changes in the regional climate patterns resulting in lower rainfall and tidal depression during the hot part of the year being suggested as the cause of the dieback.

Several studies have documented that increasing salinity in upstream reaches of an estuary will decrease biomass accumulation of foundation freshwater plant species (Sutter et al. 2014, 2015; Neubauer et al. 2005). In microcosm studies, Sutter et al. (2015) found that even smooth cordgrass (Spartina alterniflora), a salt marsh foundation species on the western Atlantic, had reduced growth when exposed to increased salinity and grown with the invasive strain of tall common reed (Phragmites australis).

An example of range extension of benthic fauna is found in the herbaceous salt marsh fiddler crab (Uca pugnax) that burrows in marsh soil. Historically, the range of the fiddler crab has been limited along the northwestern Atlantic coast to waters south of Cape Cod, Massachusetts. Its range recently has expanded northward where it has been observed on the coast of New Hampshire (Johnson 2014). The effect of fiddler crabs on C storage has been studied in Virginia salt marshes where Thomas and Blum (2010) found that $74 \%$ more root material was decomposed in marshes with fiddler crab burrows. Unless potential predators and competitors accompany crab migration, this range extension could lead to significant release of $\mathrm{CO}_{2}$ to the atmosphere from northern salt marsh $\mathrm{C}$ sinks.

Saltwater wetlands are effective natural C sinks until they are disturbed, degraded, or destroyed by draining them for urban development, agriculture, aquaculture or by other means. Rising sea levels will also degrade these ecosystems. Disturbing wetland hydrology can enable oxygen to oxidize stored soil organic matter. Drying wetland soils increases microbial decomposition of stored organic $\mathrm{C}$ causing these natural sinks to become sources of $\mathrm{CO}_{2}$ emissions (Pendleton et al. 2012). Preventing loss of these ecosystems is a priority to avoid additional GHG emissions. Restoring degraded or lost saltwater wetlands can regenerate their ability to remove and sequester $\mathrm{CO}_{2}$ from the atmosphere.

\section{Part 2: Emerging Policies and Management Strategies for Protection of Wetlands and Their Ecosystem Services in the Context of a Changing Climate}

At all levels of government, policies and management strategies that reference the relationship between wetlands and climate change may be found both in entities and policies that primarily focus on wetlands and in those that primarily focus on climate change. While wetlands are not mentioned explicitly in any of the formal climate change treaties, their relevance may be inferred under the definitions of "sources, sinks and reservoirs" for GHGs. More recently, they have been mentioned explicitly in a North American agreement among three heads of state. Wetland scientists, policy makers and managers can therefore utilize both wetlands and climate change policies and management strategies.

Recommendations for policy and management address both the role of wetlands in climate regulation, such as conserving and sustainably managing stored carbon (Nahlik and Fennessy 2016), and the role of wetlands in provision of ecological and human community climate adaptation and resiliency ecosystem services. Resiliency functions and services include flood storage, buffering of storm damage, protecting water quality by filtering pollutants and sediment out of runoff generated by severe storm events, groundwater recharge and provision of water supply during drought, provision of wildlife refuges and corridors and maintenance of biodiversity (Junk et al. 2013; Association of State Wetland Managers 2015a; Narayan et al. 2016), regulating microclimate (Zhang et al. 2016) and physically buffering coasts from sea level rise and increases in storm surges (Millennium Ecosystem Assessment 2005), as well as others enumerated elsewhere in this article. Anderson et al. (2016a) state, "Protecting wetlands and riparian corridors has been suggested as one of the single best actions in promoting resilience and in sustaining biodiversity (Naiman et al. 1993, Fremier et al. 2015)".

\section{International Wetland and Climate Policy}

In the following sections, we explore several examples of how international policy can influence the management and protection of wetlands, including their climate mitigation and adaptation/resiliency benefits, with examples from the climate policy setting (IPCC Wetlands Supplement, UN Framework Convention on Climate Change, Paris Climate Agreement, Secretariat of the Pacific Regional Environment Programme, (SPREP), The European Union Water Framework Directive and North American Action 
plan, and one from the wetlands policy setting, Ramsar). Wetlands sit at the intersection of three Sustainable Development Goals: Number 13, Climate Change; number 14, Life Below Water; and number 15 Life on Land (Sustainable development goals 2015).

\section{Climate Treaties: Greenhouse Gas Inventories and Related Mechanisms}

Initial steps to incorporate wetlands into international climate policies are now in place. In 2013, the Intergovernmental Panel on Climate Change, which provides guidance to countries on how to compile their national GHG inventories, released a Wetlands Supplement (IPCC Wetlands Supplement 2014). Previous IPCC guidance did not include comprehensive information on accounting for wetlands as sources and sinks because it was determined that the science of these ecosystems was not sufficient to provide Tier I (basic) methodologies for how to include them in national inventories. The Wetlands Supplement provides guidance on how countries are to include explicitly the emissions from land use change in freshwater wetlands, including peatlands and saltwater wetlands, in their national inventories. At least 8 countries identified peatlands as playing a role in their intended Nationally Determined Contributions (NDCs): Belarus, Colombia, France, Indonesia, Malaysia, Mongolia, Peru, and Republic of Congo (NDC Registry 2016).

Although countries are not required to use the Wetlands Supplement, they were encouraged to do so and in the 2017 submissions, a few countries, including the U.S. (USEPA 2017), did include wetland emissions in their national GHG inventories. While not requiring $\mathrm{C}$ accounting from wetlands, the Wetlands Supplement is a step forward in terms of enabling countries to account for the $\mathrm{C}$ fluxes associated with wetland ecosystems and moves the world closer to requiring countries to account for the substantial emissions from these ecosystems when they are disturbed or destroyed (for more details see Sutton-Grier and Moore 2016).

There are additional mechanisms within the United Nations Framework on Climate Change (UNFCCC) regime where coastal blue carbon ecosystems, and other wetlands might be included in climate policies: Reduced Emissions from Deforestation and Degradation (REDD+), Clean Development Mechanism (CDM), and Nationally Appropriate Mitigation Actions (NAMAs) (Gordon et al. 2011; Herr et al. 2012). Traditionally, these mechanisms have focused more on terrestrial forest projects, but could include saltwater and freshwater wetlands if projects can be developed that demonstrate the effectiveness of wetlands for emissions reductions.

Reduced emissions from deforestation and forest degradation (REDD+) provide payments to restore and protect forest $\mathrm{C}$ reservoirs in developing countries to avoid $\mathrm{CO}_{2}$ emissions
(REDD 2016). The wetlands that meet the requirements would be wetland forests and mangroves. The CDM develops projects in developing countries that reduce emissions and enable those countries to sell emission reduction credits to markets like the European Trading System (CDM 2017); these projects could include coastal wetland restoration or protection projects that would help a country reduce emissions. NAMAs refer to any action that reduces emissions in developing countries and must also be part of a national governmental initiative (http://unfccc.int/focus/mitigation/items/ 7172.php) and therefore have government approval. As such, NAMAs provide a flexible framework that can permit developing countries to meet their nationally determined contributions under the Paris Climate Agreement to reduce GHG emissions as part of their development strategy. This provision has the potential to include emissions reductions from saltwater wetlands, since each country is free to define what appropriate NAMA projects are and how they are funded (NAMA 2017). There is one blue carbon NAMA project being developed in the Dominican Republic (Sutton-Grier et al. 2018). Further demonstration projects are needed to show which of these mechanisms are feasible and most effective for saltwater wetlands.

\section{Secretariat of the Pacific Regional Environment Programme}

The Secretariat of the Pacific Regional Environment Programme (SPREP) has positioned climate change as a priority under the Strategic Action Plan 2017-2026 (SPREP 2017). It is further seen as a crosscutting issue and comprises programs on adaptation, mitigation, policy and science. Addressing climate change is seen as a priority as it is already disproportionally affecting the islands of the Pacific, including impacting mangroves and freshwater wetlands (Ellison 2011; Nurse et al. 2014). Engagement with the Ramsar Convention has been renewed given the importance of wetlands in the Pacific islands and their role in climate change and disaster risk reduction.

\section{European Union}

The European Union has a robust suite of environmental legislation and policies with increased efforts towards the incorporation of climate change and coherence with other sectors. However, there are gaps in implementation and some work is still needed to ensure the resilience and sustainability of water resources (Francés et al. 2017). The European Union has considered the ecological condition of all water bodies, including wetlands, through the Water Framework Directive with an emphasis on the future protection and improvement of the water environment as essential for sustainable development. While the Directive did not specifically include climate change there have been many investigations into how climate 
change will alter aquatic ecosystems, including numerous actions, strategies and policy instruments, as well as monitoring, reporting and evaluation systems, that could significantly contribute to a broader and more comprehensive view of climate change impacts and adaptation in the water sector (Finlayson et al 2018). As the Directive will be revised in 2019, it is anticipated that climate change will be implicitly addressed as an anthropogenic pressure, and supported with common guidelines and approaches for considering resource costs and adaptation measures (Francés et al 2017). The vote by the European Parliament in January 2018 on the Renewable Energy directive called for increases in forest bioenergy and biofuels with few limitations on the consequences for wetland forests and ecosystems despite letters from scientists urging constraints (European Parliament 2018, Scientists letter 2018, Duffy et al. 2018).

\section{North American Climate, Clean Energy, and Environment Partnership Action Plan}

In June, 2016 Prime Minister Justin Trudeau of Canada, President Barack Obama of the United States and President Enrique Peña Nieto of Mexico announced the North American Climate, Clean Energy, and Environment Partnership Action Plan which explicitly identifies blue carbon preservation and restoration as mitigation actions, and the value of wetlands for climate resiliency ecosystem services, stating the intention to, "enhance the conservation and restoration of wetlands, which increase mitigation actions (blue carbon), preserve coastal ecosystems services, and reduce the potential impacts of more frequent or intense severe weather events under climate change projections" (North American Climate, Clean Energy, and Environment Partnership Action Plan 2016).

\section{Ramsar Convention}

Since 1975, the Ramsar Convention on Wetlands has provided an international policy framework for wetland management (Gardner and Davidson 2011). It comprises 169 Contracting Parties (national governments) that generally meet every 3 years to consider the state of the world's wetlands and agree on priority actions in support of the Convention's mission which is to act for the "conservation and wise use of all wetlands through local and national actions and international cooperation, as a contribution towards achieving sustainable development throughout the world." As outlined by Davidson (2016), the Convention is implemented through three "pillars": the wise use of all wetlands; the designation and management of Wetlands of International Importance (Ramsar sites), including reporting on adverse change; and international cooperation, including for shared wetlands.
Each contracting party commits to designate and manage a coherent and comprehensive national network of Ramsar sites. As of 25 February 2018, the global network of 2301 Ramsar sites covers a surface area of 2.25 million $\mathrm{km}^{2}$ or $18.6 \%$ of the most recent and reliable estimate of global wetland area (Davidson et al. 2017). This achievement represents one of the major successes of the Convention. However, efforts to maintain other wetlands have not been as successful with high rates of loss and degradation recorded throughout the $20^{\text {th }}$ Century up to the present time (Davidson 2014; Gardner et al. 2015). These general outcomes show that the Contracting Parties have had mixed success in meeting their commitments which is not surprising when fewer than half have reported activities that demonstrated how they were addressing the goals and strategies in the Convention's Strategic Plan (Finlayson 2012). The consequences of climate change for wetlands is expected to place further pressure on the ability of Contracting Parties and wetland managers to meet such goals and strategies in the future.

The Convention has recognized the significance of wetlands in managing global GHG emissions and in providing climate resiliency in addition to traditionally acknowledged ecosystem services. In 2012 and 2015, the Conference of Parties recommended a number of actions by the Parties, including:

- recognizing significant peatlands as Wetlands of International Importance in recognition of their role in $\mathrm{C}$ sequestration and storage,

- recognizing the significance of coastal blue carbon,

- recognizing the role of wetlands in providing climate resiliency services,

- recognizing the unique vulnerability of wetlands to changes in climate (Ramsar COP12 (2015) Resolution XII.11; Ramsar COP11 (2012) Resolution XI.14; Barthelmes et al. 2015).

Finlayson et al. (2017) built on the recognition that wetlands were vulnerable to climate change and examined how climate change would influence international policy-making for wetland management, and identified potential adaptation responses that may assist Contracting Parties to better meet their commitments under the Convention.

The Convention, though, has not provided specific guidance on how to meet these requirements in the context of climate change, such as how to identify appropriate reference conditions (Finlayson et al. 2016; Gell et al. 2016) and whether past reference conditions were indeed suitable under the changing conditions of the Anthropocene (Kopf et al. 2015). This lack of guidance has left important gaps in wetland policy concerning:

- how objectives and targets for wetland conservation and management could be set and revised in the light of climate change, 
- how wetland management could best address the uncertainties due to climate change,

- how managers could best monitor and evaluate the condition of wetlands that are responding to climate change,

- whether adverse change in ecological character due to climate change should be subject to the same reporting requirements.

The Australian Government has decided that it would not use the existing formal mechanisms for reporting adverse change in Ramsar sites when it was caused by climate change. This policy raises unanswered questions about the usefulness of the formal reporting mechanisms under the Convention for dealing with adverse change when caused by global pressures such as climate change. This position creates a paradox for the Convention whereby it recognizes the vulnerability of wetlands to climate change, but has not addressed the implications for its reporting mechanisms nor provided wider guidance for management given the pervasiveness of climate change as a driver of change in wetlands.

Addressing these issues will close a major gap in the guidance provided by the Convention and provide wetland managers with advice on how to respond to the deteriorating condition of wetlands worldwide (Gardner et al. 2015). Without active intervention a changed climate is expected to exacerbate the deterioration (Finlayson et al. 2006). These principles further provide support for wetland managers seeking to determine the significance of ecological change in the face of climate change, given that the Ramsar Convention has not provided guidance to address what is becoming an overarching driver of adverse change in wetlands. While international policy, such as that provided by the Ramsar Convention, can guide countries towards effective management choices, the policy responses and management itself are required at national and sub-national levels. Policies determined at the international level require national and sub-national implementation.

\section{National Policy Setting}

National policies, whether wetland or climate change, can have important impacts on wetland conservation or destruction and therefore on the ability of a country's wetlands to either contribute to climate change mitigation, adaptation and resiliency, or become additional sources of GHGs to the atmosphere. National policies also determine the effectiveness of international policy, such as those instituted by the Ramsar Convention (Finlayson 2012). Contracting Parties to the Ramsar Convention have been encouraged to develop national wetland policies; however, in 2012, fewer than $50 \%$ reported that they had developed such policies (Finlayson 2012). The relative lack of national wetland policies limits opportunities for climate change to be addressed at the national level, as it relates to wetlands. Furthermore, there is limited evidence that climate change has been specifically addressed in national wetlands laws and policies that do exist. Pittock et al. (2010) point to gaps and inconsistencies in managing wetlands under climate change with the example of the Murray-Darling Basin in Australia where climate change has not (yet) been included in water planning instruments despite a large financial investment in riverine restoration focused on water reallocations and steps to return water to the rivers and wetlands (Pittock 2013). Wetland and climate scientists, managers, and policy makers could work together to fill this gap, while in the meantime, finding opportunities within existing wetlands and climate change laws at all levels of government (from international to local) to manage and protect wetlands in a climate-informed manner.

In the United States, "Recommendations for a National Wetlands and Climate Change Initiative" (Christie and Kusler 2009) provides specific recommendations for the development of climate change policy within wetlands programs at the national, sub-national/state, and local levels. Although written for the U.S. policy setting, many of the recommendations could be implemented in other countries as well. U.S. federal agencies included wetlands and other ecosystems into climate change planning and policies in October 2014. The White House's interagency Council on Climate Preparedness and Resilience (Resilience Council) Climate and Natural Resources Working Group (CNRWG) released their "Priority Agenda for Enhancing the Climate Resilience of America's Natural Resources (Priority Agenda)". The Priority Agenda identifies a suite of actions the federal government planned to take to enhance the resilience of America's natural resources to the impacts of climate change and promote their ability to absorb $\mathrm{CO}_{2}$. Wetlands were incorporated into the Priority Agenda, including specific actions related to coastal blue carbon requiring the National Oceanic and Atmospheric Administration (NOAA) to lead a baseline study on carbon in saltwater wetlands. This baseline study became the foundation for the U.S. to include saltwater wetlands in the national GHG inventory in April 2017 (USEPA 2017). This represents important progress in tracking and managing saltwater wetlands and GHG emissions because every subsequent U.S. inventory will include saltwater wetlands each year (SuttonGrier and Moore 2016).

\section{Sub-National and Regional Policies, Strategies and Management Tools}

We now provide examples of policies, strategies, and management tools being developed at the sub-national level to address the challenge of climate change. Reflecting an understanding of the climate mitigation functions of wetlands and other ecosystems, the Government of Ontario, with the passage in 2010 of the Ontario Far North Act (Ontario Laws 2010) became the world's first political jurisdiction to enact legislation (as 
opposed to policy/guidance) that recognizes the explicit role of wetlands and other ecosystems in the global $\mathrm{C}$ cycle by stating as the third of four objectives that land-use planning ensure "the maintenance of biological diversity, ecological processes and ecological functions, including the storage and sequestration of C in the Far North". This sets a good example of regional leadership on wetland management and climate mitigation.

In the United States, the Association of State Wetland Managers survey of state wetland programs (Zollitsch and Christie 2015) indicates that 17 states report working within the wetlands programs formally to address climate change, 13 states report working informally to address climate change, 17 states report no climate change work, and data was unavailable or unknown for 3 states. Some of the states with no designated climate related projects within state wetlands programs reported that such activity is occurring at the regional and/or local level, and that "non-climate change" work aimed at addressing natural hazards and extreme precipitation events is occurring at the state level (Association of State Wetland Managers 2015b). Two examples of states that have established climate policies or plans that proactively address wetlands are discussed below.

A Massachusetts Executive Order (Massachusetts Executive Order \#569 2016), establishes a process for a statewide integrated climate change strategy and requires a framework and technical assistance for every town and city in the state to complete climate vulnerability assessments, identify adaptation strategies and begin implementing these strategies. Although wetlands and ecosystems are not specifically mentioned in the Executive Order, it is being implemented with a focus on nature-based solutions that encompass wetlands. The lesson here is that opportunities for wetland protection and restoration exist within broader climate resiliency and GHG reduction programs. A cross-disciplinary process and collaboration integrates wetlands into broader responses to the climate challenge. Such cross-disciplinary collaborations require that a broad spectrum of policy makers and managers become educated about the importance of wetlands in our response to climate change.

Massachusetts laid the groundwork for current responses by initially addressing wetland and community vulnerability to changes in climate by identifying climate impact reduction strategies in the Massachusetts Climate Change Adaptation Report (Massachusetts Office of Energy and Environmental Affairs and the Adaptation Advisory Committee 2011). The ensuing climate change strategic planning process now also requires updated coastal floodplain regulations.

The state of Michigan has developed a Climate Change Adaptation Plan for Coastal and Inland Wetlands in the State of Michigan (Christie and Bostwick 2012), which identifies climate impacts to wetlands, surveys similar efforts in other states, discusses the role of wetlands in climate mitigation and adaptation, suggests approaches for integrating wetlands into the broader Michigan Climate Action Council Climate Action Plan that establishes the framework for Michigan's comprehensive response to climate change, and provides recommendations for managing wetlands in the context of climate change.

Within the context of conventional wetland regulations in the U.S., protection of wetlands is in part dependent upon delineation of wetland boundaries, which can shift during periods of drought due to die-off of wetland vegetation. As climate changes, the incidence of drought is increasing in some regions, thus putting at risk areas that typically would be protected by wetland regulation. The US Army Corps of Engineers (USACE) North Central and Northeast Region recognizes this by allowing for modification of wetland delineation criteria during drought (i.e. less reliance on vegetation present during drought) (USACE 2012). Similar provisions could be developed in other jurisdictions elsewhere around the world, so that land that functions as a wetland under regular climate conditions is not excluded from protection or regulation during a temporary drought. This applies to ephemeral wetlands especially those that may already experience long periods of drought that may be extended as the climate changes.

Science-based wetland and natural resource management decision-making can be adjusted to incorporate the effects of climate change on ecosystems. The Nature Conservancy (2017) has created a GIS-based mapping tool, through their Resilient and Connected Landscapes project, that maps ecologically climate-resilient and connected land in regions of the U.S. and Canada (Anderson et al. 2016a, b). Users can identify land with relatively high levels of geodiversity (i.e. diversity of bedrock, soils, and elevations), landform diversity (i.e. topographic diversity and density of wetlands), and connectedness. When combined with mapping of ecological integrity/ biological condition, this tool identifies land most likely to maintain high ecological function as climate changes (Open Space Institute and North Atlantic Conservation Cooperative 2016), and thus allows the user to prioritize conservation investments in the context of a changing climate. Because wetlands create temperature and humidity gradients on the landscape, TNC prioritizes landscapes with a high density of wetlands as being more resilient, other factors being equal. Additionally, these maps allow wetland scientists to understand the likely long-term ecological viability of wetlands in a larger landscape context.

\section{Local and Project-level Strategies and Best Management Practices: Application of Carbon Management and Climate Resiliency Science}

Many authors have assessed the amount of $\mathrm{C}$ that can be accumulated in wetland soils to address climate change. 
Some, such as Page and Baird (2016) have carefully considered the evidence and pointed to the uncertainties as well as the strengths of such evidence for particular peatland ecosystems.

Conserving, restoring, and halting disturbance of wetlands, and creating saltwater wetlands, are essential for maintaining the existing terrestrial $\mathrm{C}$ sink and supporting natural processes that sequester $\mathrm{C}$ from the atmosphere into wetland soil and biomass. Increasing wetland productivity would also help if means for doing so across large areas could be found. If a goal is to increase the amount $\mathrm{CO}_{2}$ sequestrated by wetlands, it is worth considering how much wetland restoration or creation would be needed to make a significant difference. The annual amount of $\mathrm{CO}_{2}$ sequestered by wetlands can be estimated using the data provided by Bridgham et al. (2006) for the annual average rate of $C$ sequestration by wetlands $(\sim 23$ $\left.\mathrm{gCm}^{-2} \mathrm{y}^{-1}\right)$, and the most recent estimate of the global wetland area $\left(12,100,000 \mathrm{~km}^{2}\right)$ provided by Davidson et al. (2017). Using these values, the annual amount of $\mathrm{CO}_{2}$ sequestrated is equivalent to $278 \mathrm{TgCy}^{-1}$. This equals $6 \%$ of the current 4.4 $\mathrm{PgCy}^{-1}$ net annual increase in atmospheric $\mathrm{CO}_{2}$. Hence, the area of new wetlands needed to remove one percent of the current annual increase in atmospheric $\mathrm{CO}_{2}$ is about $2,000,000 \mathrm{~km}^{2}$; an increase of about $17 \%$. This is only a very approximate estimate as the rate of sequestration is not equal across all wetlands, and it does not take into account the time period for restored or created wetlands to reach this rate. While these calculations make simplifying assumptions about $\mathrm{C}$ content and rates of sequestration, they demonstrate the importance of retaining existing wetlands, particularly vulnerable high-C sequestering wetland types such as saltwater wetlands, forested wetlands, peatlands, and permafrost, as carbon sinks, and curbing temperature rise to avoid releasing GHGs as wetlands warm.

Moving forward, it is important to examine new approaches to wetland management and governance. There is a strong potential to generate new private investment in saltwater wetland restoration and management efforts by linking these projects to the voluntary and compliance $\mathrm{C}$ markets. For example, a "Methodology for Tidal Wetland and Seagrass Restoration" (VM0033) was approved in 2015 by the Verified Carbon Standard (VCS). This methodology provides a means for managers and voluntary carbon market project developers anywhere in the world to initiate tidal saltwater wetland restoration projects for GHG credits. The methodology includes project eligibility criteria for receiving voluntary carbon credits and accounting procedures within voluntary markets, and is available for use for carbon crediting by projects that have net benefits when compared to the baseline scenario (e.g. $\mathrm{CO}_{2}, \mathrm{CH}_{4}$, and $\mathrm{N}_{2} \mathrm{O}$ ). This methodology can be used globally by project developers to generate GHG (carbon) credits for tidal wetland and seagrass restoration activities and used by the saltwater coastal restoration and management community to begin to design projects.
The American Carbon Registry (American Carbon Registry 2017) has approved a few C credit methodologies for wetlands in the Gulf of Mexico, and California's GHG cap-and-trade program incorporates $\mathrm{C}$ credits from rice cultivation activities (California GHG cap and trade California Cap and Trade 2017). The development of these voluntary carbon market methodologies is a critical step toward facilitating $\mathrm{C}$ credits in support of saltwater coastal restoration. At current voluntary carbon market prices, revenue generated from the voluntary carbon market is likely not enough to pay for the full costs of saltwater coastal restoration projects; however, $\mathrm{C}$ financing can act as an incentive for additional investment in, or joint funding of, saltwater coastal restoration, and can provide key support for long-term project monitoring. Further details are provided by Sutton-Grier and Moore (2016).

Thinking globally and acting locally, wetland managers can incorporate carbon management and climate resiliency science into project-level work (including developing a body of climate-related Best Management Practices), whether or not governing policies and regulations exist. As noted earlier in this article, avoidance of impacts to wetlands, and associated carbon stocks and processes, is likely to be the most effective management practice for preventing increases in GHG emissions from wetlands, protecting climate resiliency functions, and protecting traditional wetland ecosystem services, and it is therefore important for managers to understand the underlying science. The vast majority of wetlands store more carbon than they release to the atmosphere on an annual basis, and thus are net $\mathrm{C}$ sequesterers. Recently created freshwater wetlands may, in many cases, have a net warming effect because the cumulative radiative forcing from increased $\mathrm{CH}_{4}$ emissions exceeds the reduction of radiative forcing from sequestered $\mathrm{CO}_{2}$ until there is a "switchover point." Once the radiative forcing (now a reduced value) of sequestered $\mathrm{CO}_{2}$ exceeds the radiative forcing by emissions from $\mathrm{CH}_{4}$ and $\mathrm{N}_{2} \mathrm{O}$, the created freshwater wetland has a cooling effect on climate. It may take decades to thousands of years to reach the switchover point (Bridgham et al. 2014; Neubauer 2014; Neubauer and Megonigal 2015). The findings in these studies highlight the impact of time on soil structure, microbial communities and rooting, and associated GHG emissions from wetlands. This reinforces the importance of protecting existing wetlands wherever possible to maintain their climate mitigation (and other) functions. On the other hand, because the biogeochemistry of saltwater wetlands is different from that of freshwater systems, restored or created saltwater wetlands become $\mathrm{C}$ sinks that reestablish their climate mitigation benefits rapidly.

It is important to find Best Management Practices that can minimize GHG emissions during freshwater wetland restoration and creation projects at the local level. Common practice in freshwater wetland creation is for soils to be composed of 
composite mixes or from soils that have been removed from wetland impact areas and are then stockpiled, re-applied to the created wetland, and planted with nursery stock and seed. Typically, these soils are structurally and functionally disrupted by heavy machinery and stockpiling, which provides an opportunity to oxidize SOC and cause loss of soil structure and microbial communities. The disruption of soil structure and microbial communities resets the ecological clock, thus reducing or eliminating the beneficial effects of time on soil biogeochemical processes (Janzen 2016). Several studies indicate that transplanting intact wetland soil and/or vegetation to wetland restoration or creation sites reduces GHG emissions, compared to common practices noted above (Wilhelm et al. 2015; Murray et al. 2017; Cagampan and Waddington 2008; Waddington et al. 2009). Brown and Bedford (1997) found that transplanting intact blocks of wetland soil results in more successful establishment of wetland species, while reducing the presence of invasive plants during restoration of drained wetlands. In cases where wetland impacts are unavoidable, transplanting intact impact area $\mathrm{O}$ and A horizons (i.e. the upper soil layers with high SOC content) that contain intact herbaceous and shrub vegetation to the wetland creation site may facilitate $\mathrm{C}$ storage, climate resiliency, and traditional ecosystem services by transplanting soil structure, microbial communities, and rooted vegetation. Where the wetland restoration or creation site is in relative proximity to the wetland impact area, costs are likely to be reduced compared to traditional wetland construction costs by moving impact area soil only once, avoiding costs associated with stockpile sedimentation and erosion control, and avoiding or reducing nursery stock and seed purchases.

More research on the scale of potential GHG benefits associated with transplanting relatively intact $\mathrm{O}$ and $\mathrm{A}$ soil horizons and relatively intact surface vegetation is needed. The US Army Corps of Engineers (USACE) New England District mitigation guidance document refers to "block transplanting" (USACE 2010), but does not identify the importance of protecting the complete $\mathrm{O}$ and $\mathrm{A}$ soil horizons, or the role in $\mathrm{C}$ protection and GHG emission minimization. Wetland scientists and managers could include incorporation of climate resiliency and GHG management strategies into specific projects, as well as provide education on ecological climate resiliency, ecological $\mathrm{C}$ management, and climate change communication to a broader audience.

\section{Conclusions and Recommendations}

This article documents recent research that demonstrates the important role that wetlands play in moderating climate change and protecting communities from the impacts of a changed climate system. At the same time, these wetland ecosystems are particularly vulnerable to changes in climate.
Meeting the Paris Climate Agreement temperature goals can only be achieved in practice by greatly reducing emissions of GHGs into the atmosphere and simultaneously, actively removing $\mathrm{CO}_{2}$ from the atmosphere. Yet many wetland scientists, ecosystem managers and natural resource policy-makers are unaware of the important $\mathrm{C}$ storage role of wetlands, and how to incorporate $\mathrm{C}$-cycle considerations into wetland management and policy. Meanwhile, many climate scientists, as well as national and international policy makers, undervalue the role that wetland management might play in the future trajectory of climate change on the global scale and do not require reporting of wetland emissions or removal of GHGs (IPCC Wetlands Supplement 2014).

To play a more effective role in climate change mitigation and adaptation/resiliency, wetland scientists need to clearly communicate the significance of wetlands to the wellbeing of society and the economy. Communicating with policy makers and the public requires aligning wetland science and specific climate mitigation and adaptation/resiliency ecosystem services with the concerns and mindset of the audience (Leiserowitz et al. 2015, 2017; Roser Renouf et al. 2016; Yale Program on Climate Change Communication (YPCCC 2017); Center for Research on Environmental Decisions 2009). Studies by Cook et al. $(2013,2016)$ document that $97 \%$ of climate scientists agree that anthropogenic climate change is occurring. The near universal agreement among climate scientists can create confidence in the public to support action, but in addition, it is essential to make clear the science that is behind the consensus. Similar findings are documented by several other studies (Doran and Zimmerman 2009; Anderegg 2010; IPCC Wetland Supplements 2014). While TNC resiliency mapping, referred to earlier, and YPCCC research is specific to the U.S.A. and Canada, the concepts underlying their work can be applied around the world to develop wetland-related ecological climate resiliency mapping, and communicate effectively about climate change and wetlands.

The important role that wetlands play in sequestering $\mathrm{C}$ from the atmosphere needs to be better appreciated by wetland and climate scientists as well as by policy makers. Climate is a global issue, and the policy section of this paper illustrates the importance of incorporating both wetlands and climate change into international agreements. On the other hand, all wetlands are local and require protection or restoration at appropriate regional and local scales. We identify examples of policies that direct management practices at those scales, thus creating a multilayered management structure for maximum effectiveness (Moomaw et al. 2016). This coordinated approach can provide resilient wetland ecosystem services and protect communities using policies that buffer wetlands from climate impacts while addressing global climate change itself. Transdisciplinary research that integrates local wetland conservation with global climate change provides an important 
tool for stabilizing "greenhouse gas concentrations in the atmosphere at a level that would prevent dangerous anthropogenic interference with the climate system" (UNFCCC 1992).

Acknowledgements This collaborative paper resulted from the 2015 Society of Wetland Scientists Annual Meeting (Changing Climate. Changing Wetlands.) in Providence, Rhode Island, USA, and discussions with the 2015-2016 SWS Executive Board. Most of the authors were plenary or panel speakers, or organizers of that conference. The authors would like to thank our three reviewers for their tremendously helpful comments and ideas that significantly contributed to improving this article. In addition, we would like to acknowledge the comments and suggestions of Royal Gardner, Professor of Law and Director, Institute for Biodiversity Law and Policy at Stetson University College of Law and Chair of the Scientific and Technical Review Panel (STRP) for the Ramsar Convention on Wetlands; Marla J. Stelk, Policy Analyst at the Association of State Wetland Managers; and Jim Grace, U.S. Geological Survey, Wetland and Aquatic Research Center.

\section{Compliance with Ethical Standards}

Conflict of Interest The authors declare no conflict of interest with any data, information or analysis provided in this manuscript. Any use of trade, firm or product names is for identification purposes only and does not imply endorsement by the U.S. Government or any of the author's institutions.

Open Access This article is distributed under the terms of the Creative Commons Attribution 4.0 International License (http:// creativecommons.org/licenses/by/4.0/), which permits unrestricted use, distribution, and reproduction in any medium, provided you give appropriate credit to the original author(s) and the source, provide a link to the Creative Commons license, and indicate if changes were made.

\section{References}

American Carbon Registry (2017) http://americancarbonregistry.org/ carbon-accounting/standards-methodologies/restoration-ofdegraded-deltaic-wetlands-of-the-mississippi-delta Accessed 23 Oct 2017

Anderegg WRL (2010) Expert credibility in climate change. Proceedings of the National Academy of Sciences 107(27):12107-12109. https:// doi.org/10.1073/pnas1003187107

Anderson MG, Barnett A (2017) Resilient coastal sites for conservation in the Northeast and Mid-Atlantic US. The Nature Conservancy, Eastern Conservation Science

Anderson MG, Barnett A, Clark M, Ferree C, Olivero Sheldon A, Prince J (2016a) Resilient sites for terrestrial conservation in eastern North America The Nature Conservancy, Eastern Conservation. Science: $1-186$

Anderson MG, Barnett A, Clark M, Prince J, Olivero Sheldon A, Vickery B (2016b) Resilient and connected landscapes for terrestrial conservation. The Nature Conservancy, Eastern Conservation Science, Eastern Regional Office Boston, MA, pp 1-149

Arkema KK, Guannel G, Verutes G, Wood SA, Guerry A, Ruckelshaus M, Kareiva P, Lacayo M, Silver JM (2013) Coastal habitats shield people and property from sea-level rise and storms. Nature Climate Change 3:913-918j. https://doi.org/10.1038/NCLIMATE1944

Association of State Wetland Managers (2015a) Wetlands and climate change: Considerations for wetland program managers. Maine, $p p$ 6-7
Association of State Wetland Managers (2015b) Wetlands and climate change: Considerations for wetland program managers. Maine, pp 8-9

Barbier EB (2014) Climate change mitigation policies and poverty. WIREs Climate Change 5:483-491. https://doi.org/10.1002/wcc. 281

Barbier EB, Hacker SD, Kennedy C, Koch EW, Stier AC, Silliman BR (2011) The value of estuarine and coastal ecosystem services. Ecological Monographs 81(2):169-193

Baron JS, Poff NL, Angermeier PL, Dahm CN, Gleick PH, Hairston NG Jr, Jackson RB, Johnston CA, Richter BD, Steinman AD (2002) Meeting ecological and societal needs for freshwater. Ecological Applications 12:1247-1260

Barthelmes, A, Couwenberg J, Risager M, Tegetmeyer C, Joosten H (2015) Peatlands and climate in a Ramsar context, a Nordic-Baltic perspective. Nordic Council of Ministers. TemaNord 2015:544. doi. org/10.6027/

Bernstein L, Bosch P, Canziani O, Chen Z, Christ R, Davidson O, Hare W, Huq S, Karoly D, Kattsov V, Kundzewicz Z, Liu J, Lohmann U, Manning M, Matsuno T, Menne B, Metz B, Mirza M, Nicholls N, Nurse L, Pachauri R, Palutikof J, Parry M, Qin D, Ravindranath N, Reisinger A, Ren J, Riahi K, Rosenzweig C, Rusticucci M, Schneider S, Sokona Y, Solomon S, Stott P, Stouffer R, Sugiyama T, Swart R, Tirpak D, Vogel C, Yoh G. (2007) Intergovernmental Panel on Climate Change. Fourth Assessment Report, Climate Change 2007: synthesis report. IPCC Secretariat, World Meteorological Organization, Geneva

Bianchi TS, Allison MA, Zhao J, Li X, Comeaux RS, Feagin RA, Kulawardhana RW (2013) Historical reconstruction of mangrove expansion in the Gulf of Mexico: Linking climate change with carbon sequestration in coastal wetlands. Estuarine, Coastal and Shelf Science 119:7-16. https://doi.org/10.1016/j.ecss.2012.12.007

Bond TC, Doherty SJ, Fahey DW, Forster PM, Berntsen T, DeAngelo BJ, Flanner MG, Ghan S, Kärcher B, Koch D, Kinne S, Kondo Y, Quinn PK, Sarofim MC, Schultz MG, Schulz M, Venkataraman C, Zhang H, Zhang S, Bellouin N, Guttikunda SK, Hopke PK, Jacobson MZ, Kaiser JW, Klimont Z, Lohmann U, Schwarz JP, Shindell D, Storelvmo T, Warren SG, Zender CS (2013) Bounding the role of black carbon in the climate system: A scientific assessment. Journal of Geophysical Research - Atmospheres 118:2169-8996. https:// doi.org/10.1002/jgrd.50171

Bridgham SD, Megonigal JP, Keller JK, Bliss NB, Trettin C (2006) The carbon balance of North American wetlands. Wetlands 26(4):889 916

Bridgham SD, Moore TR, Richardson CJ, Roulet NT (2014) Errors in greenhouse forcing and soil carbon sequestration estimates in freshwater wetlands; a comment on Mitsch et al. (2013). Landscape Ecology 29(9):1481-1485. https://doi.org/10.1007/s10980-0140067-2

Brinson MM, Lugo AE, Brown S (1981) Primary productivity, decomposition and consumer activity in freshwater wetlands. Annual Review of Ecology and Systematics 12:123-161

Brown SC, Bedford BL (1997) Restoration of wetland vegetation with transplanted wetland soil: an experimental study. Wetlands 17(3): 424-437. https://doi.org/10.1007/BF03161432

Cagampan JP, Waddington JM (2008) Net ecosystem $\mathrm{CO}_{2}$ exchange of a cutover peatland rehabilitated with a transplanted acrotelm. Ecoscience 15(2):258-267. https://doi.org/10.2980/15-2-3054

California Cap and Trade (2017) California air resources board compliance offset protocol rice cultivation projects. https://www.arb.ca.gov/cc/ capandtrade/protocols/riceprotocol103015.htm. Accessed 15 Oct 2017

CDM (2017) Clean Development Mechanism United Nations Framework Convention on Climate Change https://cdm.unfccc. int/. Accessed 15 Oct 2017

Center for Research on Environmental Decisions (2009) The psychology of climate change communication: a guide for scientists, journalists, educators, political aides, and the interested public. New York, pp 148 
Charles H, Dukes JS (2009) Effects of warming and altered precipitation on plant and nutrient dynamics of a New England salt marsh. Ecological Applications 19:1758-1773

Chmura GL, Coffey A, Crago R (2001) Variation in surface sediment deposition on salt marshes on the Bay of Fundy. Journal of Coastal Research 17(1):221-227

Chmura GL, Anisfeld S, Cahoon D, Lynch J (2003) Global carbon sequestration in tidal, saline wetland soils. Global Biogeochemical Cycles 17(4):22.1-22.12. https://doi.org/10.1029/2002GB001917

Chmura GL, Kellman L, van Ardenne L, Guntenspergen GR (2016) Greenhouse gas fluxes from salt marshes exposed to chronic nutrient enrichment. PLOS One 11(2):e0149937. https://doi.org/10.1371/ journal.pone. 0149937

Christensen TR, Johansson T, Åkerman J, Mastepanov M, Malmer N, Friborg T, Crill P, Svensson BH (2004) Thawing sub-arctic permafrost: Effects on vegetation and methane emissions. Geophysical Research Letters 31:L04501. https://doi.org/10.1029/ 2003GL018680

Christie J, Bostwick P (2012) Climate change adaptation plan for coastal and inland wetlands in the state of Michigan. A white paper prepared for the Michigan Department of Environmental Quality Wetlands Program and Coastal Management Program. Association of State Wetlands Managers Windham Maine https://www.aswm.org/pdf lib/michigan_wetlands_and_climate_change_report_final_ 403251_7.pdf Accessed 15 Oct 2017

Christie J, Kusler J (2009) Recommendations for a national wetlands and climate change initiative Association of State Wetland Managers New York, pp 1-19. https://www.aswm.org/pdf_lib/ recommendations 2008 112008.pdf. Accessed 15 Oct 2017

Church JA, Monselesan D, Gregory JM (2013) Marzeion B (2013) Evaluating the ability of process based models to project sea-level change. Environmental Research Letters 8:014051 (8pp). https:// doi.org/10.1088/1748-9326/8/1/014051

Ciais P, Sabine C, Bala G, Bopp L, Brovkin V, Canadell J, Chhabra A, DeFries R, Galloway J, Heimann M, Jones C, Le Quéré C, Myneni RB, Piao S, Thornton P (2013) Carbon and other biogeochemical cycles, Chapter 6. In: Stocker TF, Qin D, Plattner GK, Tignor M, Allen SK, Boschung J, Nauels A, Xia Y, Bex V, Midgley PM (eds) Climate change 2013: the physical science basis. Contribution of Working Group I to the fifth assessment report of the Intergovernmental Panel on Climate Change. Cambridge University Press, Cambridge

Collins M, Knutti R, Arblaster J, Dufresne J-L, Fichefet T, Friedlingstein P, Gao X, Gutowski WJ, Johns T, Krinner G, Shongwe M, Tebaldi C, Weaver AJ, Wehner M (2013) Long-term climate change: Projections, commitments and irreversibility. In: Stocker TF, Qin D, Plattner G-K, Tignor M, Allen SK, Doschung J, Nauels A, Xia Y, Bex V, Midgley PM (eds) Climate change 2013: The physical science basis. Contribution of Working Group I to the Fifth Assessment Report of the Intergovernmental Panel on Climate Change. Cambridge University Press, Cambridge, pp 1029-1136. https://doi.org/10.1017/CBO9781107415324.024

Cook J, Nuccitelli D, Green SA, Richardson M, Winckler B, Painting R, Way R, Jacobs P, Skuce A (2013) Quantifying the consensus on anthropogenic global warming in the scientific literature. Environ Res Lett 8 024024. https://doi.org/10.1088/1748-9326/8/2/024024 http://www.stacks.iop.org/ERL/8/024024. Accessed 23 Oct 2017

Cook BI, Ault TR, Smerdon JE (2015) Unprecedented 21st century drought risk in the American Southwest and Central Plains. Science Advances 1:e1400082

Cook J, Oreskes N, Doran PT, Anderegg WRI, Verheggen B, Maibach EW, Carlton JS, Lewendowsky S, Skuce AG, Green SA, Nuccitelli D, Jacobs P, Richardson M, Winkler B, Painting R, Rice K (2016) Consensus on consensus: A synthesis of consensus estimates on human-caused global warming. Environmental Research Letters 11(4) (7pp)). https://doi.org/10.1088/1748-936/11/4/048002
Costanza R, Perez-Maqueo O, Martinez ML, Sutton P, Anderson SJ, Mulder K (2008) The value of coastal wetlands for hurricane protection. Ambio 37(4):241-248

Dale P, Eslami-Andargoli L, Knight J (2013) The impact of encroachment of mangroves into saltmarshes on saltwater mosquito habitats. Journal of Vector Ecology 38(2):330-338

Davidson NC (2014) How much wetland has the world lost? Long-term and recent trends in global wetland area. Marine and Freshwater Research 65(10):934-941. https://doi.org/10.1071/MF14173

Davidson NC (2016) The Ramsar Convention on Wetlands. In: Finlayson CM, Everard M, Irvine K, McInnes RJ, Middleton BA, van Dam AA, Davidson NC (eds) (2016) The wetland book I: Structure and function, management and methods. Springer Publishers, Dordrecht. https://doi.org/10.1007/978-94-007-6172-8 113-1

Davidson NC, Fluet-Chouinard E, Finlayson CM (2017) Global extent and distribution of wetlands: Trends and issues. Marine and Freshwater Research (in press)

Deemer BR, Harrison JA, Li S, Beauliey JJ, DeLSontro T, Barros N, Bezerra-Neto JF, Powers SM, Dos Santos MA, Vonk JA (2016) Greenhouse gas emissions from reservoir water surfaces: A new global synthesis. BioScience 66:949-964. https://doi.org/10.1093/ biosci/biw117

Delaune RD, White JR (2012) Will coastal wetlands continue to sequester carbon in response to an increase in global sea level? A case study of the rapidly subsiding Mississippi river deltaic plain. Climatic Change 110:297. https://doi.org/10.1007/s10584-011-0089-6

Donato DC, Kauffman JB, Murdiyarso D, Kurnianto S, Stidham M, Kanninen M (2011) Mangroves among the most carbon-rich forests in the tropics. Nature Geoscience 4:293-297. https://doi.org/10. 1038/ngeo1123

Doran PT, Zimmerman MK (2009) Examining the scientific consensus on climate change. Eos 90(3):22-23

Doughty CL, Langley JA, Walker WS, Feller IC, Schaub R, Chapman SK (2015) Mangrove expansion rapidly increases coastal wetland storage. Estuaries and Coasts. https://doi.org/10.1007/s12237-0159993-8

Duarte CM, Losada IJ, Hendriks IE, Mazarrasa I, Marbà N (2013) The role of coastal plant communities for climate change mitigation and adaptation. Nature Climate Change 3:961-968. https://doi.org/10. 1038/nclimate1970

DuBowy PJ (2013) Mississippi River ecohydrology: Past, present and future. Ecohydrology and Hydrobiology 13:73-83

Duffy PB et al (2018) Letter from American Scientists to Members of the EU Parliament Regarding Forest Biomass. January 8:2018 http:// www.ase.tufts.edu/

Duke NC, Kovacs JM, Griffiths AD, Preece L, Hill DJE, van Oosterzee P, Mackenzie J, Morning HS, Burrows D (2017) Large-scale dieback of mangroves in Australia's Gulf of Carpentaria: A severe ecosystem response, coincidental with an unusually extreme weather event. Marine and Freshwater Research. https://oi.org/10.1071/ MF16322

Ellison JC (2011) Regional wetlands action plan for the Pacific islands. In: Secretariat of the Pacific Regional Environment (SPREP). Apia, Samoa

Ellison JC (2008) Long-term retrospection on mangrove development using sediment cores and pollen analysis: A review. Aquatic Botany 89:93-104

Enwright NM, Griffith KT, Osland MJ (2016) Barriers to and opportunities for landward migration of coastal wetlands with sea level rise. Frontiers in Ecology and the Environment 14(6):307-316

Erwin KL (2009) Wetlands and global climate change: the role of wetland restoration in a changing world. Wetlands Ecology and Management 17:71-84. https://doi.org/10.1007/s11273-008-9119-1

European Parliament (2018) MEPs set ambitious targets for cleaner, more efficient energy use 17 January 2018 http://www.europarl.europa. 
eu/news/en/press-room/20180112IPR91629/meps-set ambitioustargets-for-cleaner-more-efficient-energy-use

Evans CD, Renou-Wilson F, Strack M (2015) Inclusion of waterborne carbon in IPCC greenhouse gas emissions accounting for drained and re-wetted peatlands: Development of the methodology and future research needs. Aquatic Sci. https://doi.org/10.1007/s00027015-0447-y

Feher LC, Osland MJ, Griffith KT, Grace JB, Howard RJ, Stagg CL, Enwright NM, Krauss KW, Gabler CA, Day RH, Rogers K (2017) Linear and nonlinear effects of temperature and precipitation on ecosystem properties in tidal saline wetlands. Ecosphere 8(10): e01956. https://doi.org/10.1002/ecs2.1956

Finlayson CM (2012) Forty years of wetland conservation and wise use. Aquatic Conservation: Marine and Freshwater Ecosystems 22:139 143

Finlayson CM, Gitay H, Bellio M-G, van Dam RA, Taylor I (2006). Climate variability and change and other pressures on wetlands and waterbirds - Impacts and adaptation. In: Boere G, Gailbraith C, Stroud D (eds) Water birds around the world Scottish Natural Heritage Edinburgh UK, pp 88-89

Finlayson CM, Clarke SJ, Davidson N, Gell P (2016) Role of paleoecology in describing the ecological character of wetlands. Marine and Freshwater Research 67(68):7-694

Finlayson CM, Capon SJ, Rissik D, Pittock J, Fisk G, Davidson NC, Bodmin KA, Papas P, Robertson HA, Schallenberg M, Saintilan N, Edyvane K, Bino G (2017) Policy considerations for managing wetlands under a changing climate. Marine and Freshwater Research 68:1803-1815

Finlayson CM, Davidson NC, Gel PA, Kumar R, McInnes RJ (2018) Managing freshwater protected areas in the global landscape. In: Finlayson CM, Arthington AH, Pittock J (eds) Freshwater Ecosystems in Protected Areas: Conservation and Management. Taylor and Francis, Oxford, pp 221-241

FitzGerald DM, Fenster MS, Argow BA, Buynevich IV (2008) Coastal impacts due to sea-level rise. Annual Review of Earth and Planetary Sciences 36:601-647

Fourqurean JW, Duarte CM, Kennedy H, Marbà N, Holmer M, Mateo MA, Apostolaki ET, Kendrick GA, Krause-Jensen D, McGlathery KJ, Serrano O (2012) Seagrass ecosystems as a globally significant carbon stock. Nature Geoscience 5:505-509. https://doi.org/10. 1038/ngeo1477

Fremier A, Kiparsky M, Gmur S, Aycrigg J, Kundis Criag R, Svancara LK, Goble DD, Cosens B, Davis F, Scott JM (2015) A riparian conservation network for ecological resilience. Biological Conservation 191:29-37

Francés GE, Quevauviller P, González ESM, Amelin EV (2017) Climate change policy and water resources in the EU and Spain. A closer look into the Water Framework Directive. Environmental Science \& Policy 69:1-12

Friedlingstein P, Andrews RM, Roegelj J, Peters GP, Candell JG, Knutti R, Liderer G, Raupach MR, Schaeffer M, van Vuuren DP, Le Quéré $\mathrm{C}$ (2014) Persistent growth of $\mathrm{CO}_{2}$ emissions and implications for reaching climate targets. Nature Geoscience 7:709-715

Frolking S, Roulet NT (2007) Holocene radiative forcing impact of northern peatland carbon accumulation and methane emissions. Global Change Biology 13(5):1079-1088

Frolking S, Roulet NT, Tuittila E, Bubier JL, Quillet A, Talbot J, Richard PJH (2010) A new model of Holocene peatland net primary production, decomposition, water balance, and peat accumulation. Earth System Dynamics 1:1-21. https://doi.org/10.5194/esd-1-1-2010 http://www.earth-syst-dynam.net/1/1/2010. Accessed 23 Oct 2017

Gardner RC, Davidson NC (2011) The Ramsar Convention. In: LePage B (ed) Wetlands - integrating multidisciplinary concepts. Springer, Dordrecht, pp 189-203

Gardner RC, Barchiesi S, Beltrame C, Finlayson CM, Galewski T, Harrison I, Paganini M, Perennou C, Pritchard DE, Rosenqvist A,
Walpole M (2015) State of the world's wetlands and their services to people: A compilation of recent analyses. Ramsar Convention Secretariat, Ramsar Scientific and Technical Briefing Note No. 7, Gland

Gedan KB, Bertness MD (2010) How will warming affect the salt marsh foundation species Spartina patens and its ecological role? Oecologia 164:479-487

Gell PA, Finlayson CM, Davidson NC (2016) Understanding change in the ecological character of Ramsar wetlands: Perspectives from a deeper time - synthesis. Marine and Freshwater Research 67:869 879

Gilman EL, Ellison JC, Duke NC, Field C (2008) Threats to mangroves from climate change and adaptation options: A review. Aquatic Botany 89:237-250

Godoy MDP, DeLacerda LD (2015) Mangroves response to climate change: A review of recent findings on mangrove extension and distribution. Anais da Academia Brasileira de Ciências (Annals of the Brazilian Academy of Sciences) https://doi.org/10.1590/00013765201520150055 Accessed 15 Oct 2017

Gordon D, Murray BC, Pendleton L, Victor B (2011) Financing options for blue carbon: Opportunities and lessons from the REDD+ experience. Duke University, Nicholas Institute for Environmental Policy Solutions

Gorham E (1991) Northern peatlands: Role in the carbon cycle and probable responses to climatic warming. Ecological Applications 1(2): $182-195$

van Groenigen KJ, Osenberg CW, Hungate BA (2011) Increased soil emissions of potent greenhouse gases under increased atmospheric $\mathrm{CO}_{2}$. Nature 475:214-216

Hanson PJ (2016) Stability of peatland carbon to rising temperatures. Nature Communications 7:13723. https://doi.org/10.1038/ ncoms 13723

Hawkins E, Ortega P, Suckling E (2017) Estimating changes in global temperatures since the pre-industrial period. Bulletin of the American Meteorological Society https://doi.org/10.1175/BAMSD-16-0007

Hayes NM, Deemer BR, Corman JR, Razavi NR, Strock KE (2017) Key differences between lakes and reservoirs modify climate signals: A case for a new conceptual model. Limnology and Oceanography Letters 2(2):47-62

Hemminga MA, Buth GJC (1991) Decomposition in salt marsh ecosystems of the S. W. Netherlands: The effects of biotic and abiotic factors. Vegetatio 92(1):73-83

Herbert ER, Boon P, Burgin AJ, Neubauer SC, Franklin RB, Ardon M, Hopfensperger KN, Lamers LPM, Gell P (2015) A global perspective on wetland salinization: Ecological consequences of a growing threat to freshwater wetlands. Ecosphere 6(10):1-43. https://doi.org/ 10.1890/ES14-00534.1

Herr D, Pidgeon E, Laffoley D (eds.) (2012) Blue carbon policy framework 2.0: Based on the discussion of the international blue carbon policy working group Gland, Switzerland: IUCN, Conservation International, and Linden Trust for Conservation, US

Hill GB, Henry GHR (2011) Responses of High Arctic wet sedge tundra to climate warming since 1980. Global Change Biology 17:276-287

Hopper T, Meixler MS (2016) Modeling coastal vulnerability through space and time. PLoS ONE 11(10):e0163495. https://doi.org/10. $1371 /$ journal

Howard J, Sutton-Grier A, Herr D, Kleypas J, Landis E, Mcleod E, Pidgeon E, Simpson S (2017) Clarifying the role of coastal and marine systems in climate mitigation. Frontiers in Ecology and Environment 15:42-50

Hugelius G, Strauss J, Zubrzycki S, Harden JW, Schuur EAG, Ping CL, Schirrmeister L, Grosse G, Michaelson GJ, Koven CD, O'Donnell JA, Elberling B, Mishra U, Camill P, Yu Z, Palmtag J Kuhry P (2014) Estimated stocks of circumpolar permafrost carbon with quantified uncertainty ranges and identified data gaps. 
Biogeosciences 11:6573-6593. https://doi.org/10.5194/bg-116573-2014

Huston MA (2012) Precipitation, soils, NPP, and biodiversity: Resurrection of Albrecht's curve. Ecological Monographs 82:277296

IEA (2017) Technology Roadmap:Delivering Siustainable Bioenergy. International Energy Agency https://www.iea.org/.../IEA_ Bioenergy Roadmap FoldOut 2ndEdition WEB.pdf

IPCC Wetland Supplements (2014) 2013 Supplement to the 2006 IPCC Guidelines for National Greenhouse Gas Inventories: Wetlands http://www.ipcc-nggip.iges.or.jp/public/wetlands/ Accessed 15 Oct 2017

Jackson ST, Hobbs RJ (2009) Ecological restoration in the light of ecological history. Science 325:567-569. https://doi.org/10.1126/ science. 1172977

Janzen HH (2016) The soil remembers. Soil Science Society of America Journal 80:1429-1432. https://doi.org/10.2136/sssaj2106.05.0143

Johnson DS (2014) Fiddler on the roof: A northern range extension for the marsh fiddler crab Uca pugnax. Journal of Crustacean Biology 34(5):671-673

Joosten H, Couwenberg J, von Unger M (2016) International carbon policies as a new driver for peatland restoration. In: Bonn A, Allot T, Evans M, Joosten H, Stoneman R (eds) Peatland restoration and ecosystem services: Science, policy and practice. Cambridge University Press/British Ecological Society, Cambridge, pp 291313

Junk WJ, An S, Finlayson CM, Gopal B, Kvet J, Mitchell A, Mitsch WJ, Robarts RD (2013) Current state of knowledge regarding the world's wetlands and their future under global climate change: a synthesis. Aquatic Sciences 75:151-167. https://doi.org/10.1007/ s00027-012-0278-z

Keddy PA (2010) Wetland ecology principles and conservation, 2nd edn. Cambridge University Press, NY, p 497

Kelleway JJ, Saintilan N, Macreadie PI, Skilbeck CG, Zawadzki A, Ralph PJ (2015) Seventy years of continuous encroachment substantially increases "blue carbon" capacity as mangroves replace intertidal salt marshes. Global Change Biology 22:1097-1109. https://doi.org/10.1111/gcb.13158

Kirschke S, Bousquet P, Ciais P, Saunois M, Canadell JG, Dlugokencky EJ, Bergamaschi P, Bergmann D, Blake DR, Bruhwiler L, CameronSmith P, Castaldi S, Chevallier F, Feng L, Fraser A, Heimann M, Hodson EL, Houweling S, Josse B, Fraser PJ, Krummel PB, Lamarque J, Langenfelds RL, Le Quéré C, Naik V, O'Doherty S, Palmer PI, Pison I, Plummer D, Poulter B, Prinn RG, Rigby M, Ringeval B, Santini M, Schmidt M, Shindell DT, Simpson IJ, Spahni R, Steele LP, Strode SA, Sudo K, Szopa S, van der Werf GR, Voulgarakis A, van Weele M, Weiss RF, Williams JE, Zeng G (2013) Three decades of global methane sources and sinks. Nature Geoscience. 6:813-823. https://doi.org/10.1038/ngeo1955

Kirwan ML, Guntenspergen GR, D’Alpaos A, Morris JT, Mudd SM, Temmerman S (2010) Limits on the adaptability of coastal marshes to rising sea level. Geophysical Research Letters 37:L23401. https:// doi.org/10.1029/2010GL045489

Kirwan ML, Guntenspergen GR, Langley JA (2014) Temperature sensitivity of organic-matter decay in tidal marshes. Biogeosciences 11: 4801-4808

Knoll LB, Vanni MJ, Renwick WJ, Kollie S (2014) Burial rates and stoichiometry of sedimentary carbon, nitrogen and phosphorus in Midwestern US reservoirs. Freshwater Biology 58(11):2342-2353. https://doi.org/10.1111/fwb.12438

Köchy M, Hiederer R, Freibauer A (2015) Global distribution of soil organic carbon - Part 1: Masses and frequency distributions of SOC stocks for the tropics, permafrost regions, wetlands, and the world. SOIL 1:351-365. https://doi.org/10.5194/soil-1-351-2015

Kopf RK, Finlayson CM, Humphries P, Sims NC, Hladyz S (2015) Anthropocene baselines: Assessing change and managing biodiversity in human-dominated aquatic ecosystems. Bioscience 65:798-811

Laine A, Nakamura H, Nishii K, Miyasaka T (2014) A diagnostic study of future evaporation changes projected in CMIP5 climate models. Clim Dyn 42:2745-2761. https://doi.org/10.1007/s00382-0142087-7

Lawler JJ (2009) Climate change adaptation strategies for resource management and conservation planning. The Year in Ecology and Conservation Biology, 2009. Annals of the New York Academy of Sciences 1162:79-98. https://doi.org/10.1111/j.1749-6632.2009. 04147.x

Le Quéré C, Andrew RM, Canadell JG, Sitch S, Korsbakken JI, Peters GP, Manning AC, Boden TA, Tans PP, Houghton RA, Keeling RF, Alin S, Andrews OD, Anthoni P, Barbero L, Bopp L, Chevallier F, Chini LP, Ciais P, Currie K, Delire C, Doney SC, Friedlingstein P, Gkritzalis T, Harris I, Hauck J, Haverd V, Hoppema M, Klein Goldewijk K, Jain AK, Kato E, Körtzinger A, Landschützer P, Lefévre N, Lenton A, Lienert S, Lombardozzi D, Melton JR, Metzl N, Millero F, Monteiro PMS, Munro DR, Nabel JEMS, Nakaoka S, O'Brien K, Olsen A, Omar AM, Ono T, Pierrot D, Poulter B, Rödenbeck C, Salisbury J, Schuster U, Schwinger J, Séférian R, Skjelvan I, Stocker BD, Sutton AJ, Takahashi T, Tian H, Tilbrook B, van der Laan-Luijkx IT, van der Werf GR, Viovy N, Walker AP, Wiltshire A, Zaehle S (2016) Global carbon budget 2016. Earth System Science Data 8:605-649. https://doi.org/10. 5194/essd-8-605-2016 http://www.earth-syst-sci-data.net/8/605/ 2016/essd-8-605-2016.pdf. Accessed 1 Sept 2017

Leiserowitz A, Maibach E, Roser-Renouf C, Feinberg G, Rosenthal S (2015) Climate change in the American mind: October 2015. Yale University and George Mason University New Haven CT: Yale Program on Climate Change Communication, pp 1-45

Leiserowitz A, Maibach E, Roser-Renouf C, Rosenthal S, Cutler M (2017) Climate change in the American mind: November 2016. Yale University and George Mason University New Haven, CT: Yale Program on Climate Change Communication, pp 1-46

Lucas R, Finlayson CM, Bartolo R, Rogers K, Mitchell A, Woodroffe $\mathrm{CD}$, Asbridge E, Ens E (2017) Historical perspectives on the mangroves of Kakadu National Park. Marine and Freshwater Research. https://doi.org/10.1071/MF17065

Malhotra A, Roulet NT (2015) Environmental correlates of peatland carbon fluxes in a thawing landscape: Do transitional thaw stages matter? Biogeosciences 12(10):3119-3130

Mallakpour I, Villarini G (2015) The changing nature of flooding across the central United States. Nature Climate Change 5:250-254

Massachusetts Executive Order \#569 (2016) Office of the Governor, Commonwealth of Massachusetts, Establishing an integrated climate change strategy for the Commonwealth. http://www.mass. gov/eea/docs/executive-order-climate-change-strategy.pdf. Accessed 15 Oct 2017

Massachusetts Office of Energy and Environmental Affairs and the Adaptation Advisory Committee (2011) Massachusetts climate change adaptation report. Boston, Massachusetts, pp 40-51

McLeod E, Chmura GL, Bouillon S, Salm R, Björk M, Duarte CM, Lovelock CE, Schlesinger WH, Silliman BR (2011) A blueprint for blue carbon: Toward an improved understanding of the role of vegetated coastal habitats in sequestering $\mathrm{CO}_{2}$. Frontiers in Ecology Environment 9(10):552-560 Figure 3. https://doi.org/10.1890/110004

Megonigal JP, Hines ME, Visscher PT (2004) Anaerobic metabolism: Linkages to trace gases and aerobic processes. In: Schlesinger WH (ed) Biogeochemistry. Elsevier-Pergamon, Oxford, pp 317-424

Mendelssohn IA, McKee KL, Postek MT (1982) Sublethal stresses controlling Spartina alterniflora productivity. In: Gopal B, Turner RE, Wetzel RG, Whigham DF (eds) Wetlands: Ecology and management. National Institute of Ecology, Jaipur, pp 223-242

Methodology for Tidal Wetland and Seagrass Restoration VM0033 v 1.0 Verified Carbon Standard (2015) http://database.v-c-s.org/ 
methodologies/methodology-tidal-wetland-and-seagrassrestoration-v10. Accessed 22 Oct 2017

Middleton BA (1999) Wetland restoration, flood pulsing and disturbance dynamics. John Wiley and Sons, New York

Middleton BA, Souter N (2016) Functional integrity of wetlands, hydrologic alteration and freshwater availability. Ecosystem Health and. Sustainability 2(1):e01200. https://doi.org/10.1002/ehs2.1200

Middleton BA, Johnson D, Roberts B (2015) Hydrologic remediation for the Deepwater Horizon Incident drove ancillary primary production increase in coastal swamps. Ecohydrology 8:838-850

Middleton BA, Boudell J, Fisichelli N (2017) Using management to address vegetation stress related to land-use and climate change. Restoration Ecology 26:1-4

Mikaloff Fletcher SE, Tans PP, Bruhwiler LM, Miller JB, Heimann M (2004) $\mathrm{CH}_{4}$ sources estimated from atmospheric observations of $\mathrm{CH}_{4}$ and its ${ }^{13} \mathrm{C} /{ }^{12} \mathrm{C}$ isotopic ratios: 2. Inverse modeling of $\mathrm{CH}_{4}$ fluxes from geographical regions. Global Biogeochemical Cycles 18, GB4005. https://doi.org/10.1029/2004GB002224

Millennium Ecosystem Assessment (2005) Ecosystems and human wellbeing: Wetlands and water synthesis. World Resources Institute, Washington, DC, p 1

Moomaw WR, Bhandary RR, Kuhl L, Verkooijen P (2016) Sustainable development diplomacy: Diagnostics for the negotiation and implementation of sustainable development. Global Policy 8(1):73-81

Murray KR, Borkenhagen AK, Cooper D, Strack M (2017) Growing season carbon gas exchange from peatlands used as a source of vegetation donor material for restoration. Wetlands Ecology and Management 25(4):501-515. https://doi.org/10.1007/s11273-0179531-5

Myhre G, Shindell D, Breon FM, Collins W, Fugelestvedt J, Huang J, Lamarque J-F, Lee D, Mendoza B, Nakajima T, Robock A (2013) Anthropogenic and natural radiative forcing. In: Stocker TF, Qin D, Plattner G-K et al (eds) Climate change 2013: The physical science basis. Contributions of Working Group I to the Fifth Assessment Report of the Intergovernmental Panel on Climate Change. Cambridge University, Cambridge

Nahlik AM, Fennessy MS (2016) Carbon storage in US wetlands. Nature Communications 7:13835:1-6. https://doi.org/10.1038/ ncomms 13835

Naiman RJ, Decamps H, Pollock M (1993) The role of riparian corridors in maintaining regional biodiversity. Ecological Applications 3(2): 209-212

NAMA (2017) Nationally Appropriate Mitigation Actions UN Framework Convention on Climate Change FOCUS: Mitigation NAMAs, Nationally Appropriate Mitigation Actions http://unfecc. int/focus/mitigation/items/7172.php. Accessed 15 Oct 2017

Narayan S, Beck MW, Wilson P, Thomas C, Guerrero A, Shepard C, Reguero BG, Franco G, Ingram CJ, Trespalacios D (2016) Coastal Wetlands and Flood Damage Reduction: Using Risk Industry-based Models to Assess Natural Defenses in the Northeastern USA. Lloyd's Tercentenary Research Foundation, London

Natali SM, Schuur EAG, Mauritz M, Schade JD, Celis G, Crummer KG, Johnston C, Krapek J, Pegoraro E, Salmon VG, Webb EE (2015) Permafrost thaw and soil moisture driving $\mathrm{CO}_{2}$ and $\mathrm{CH}_{4}$ release from upland tundra. J Geophys Res Biogeosci 120:525-537. https://doi.org/10.1002/2014JG002872

NDC Registry 2016 Communication of First NDCs under the Paris Agreement Nationally Determined Contributions United Nations Framework Convention on Climate Change

Neubauer SC (2014) On the challenges of modeling the net radiative forcing of wetlands: Reconsidering Mitsch et al 2013. Landscape Ecology 29(4):571-577. https://doi.org/10.1177/1077558711435365

Neubauer SC, Megonigal JP (2015) Moving beyond global warming potentials to quantify the climatic role of ecosystems. Ecosystems 18:1000-1013. https://doi.org/10.1007/s10021-015-9879-4
Neubauer SC, Givler K, Valentine SK, Megonigal JP (2005) Seasonal patterns and plant - mediated controls of subsurface wetland biogeochemistry. Ecology 86(12):3334-3344

NOAA 2017 National Oceanic and Atmospheric Administration U.S. Department of Commerce, U.S. Geological Survey, U.S. Environmental Protection Agency and Rutgers University, Global and regional sea level rise scenarios for the United States NOAA Technical Report NOS CO-OPS 083 techrpt83_Global_and_Regional_SLR_Scenarios_for_the_US_final.pdf. Accessed 19 Apr 2017

NOAA 2018 National Oceanic and Atmospheric Administration Earth Monitoring and Research Laboratory Global Monitoring Division Trends in atmospheric carbon dioxide Recent global monthly mean $\mathrm{CO}_{2}$ https://www.esrl.noaa.gov/gmd/ccgg/trends/global.html Accessed 26 Feb 2018

North American Climate, Clean Energy, and Environment Partnership Action Plan 2016 https://obamawhitehouse.archives.gov/the-pressoffice/2016/06/29/north-american-climate-clean-energy-andenvironment-partnership-action. Accessed 22 Oct 2017

Nurse LA, McLean RF, Agard J, Briguglio LP, Duvat-Magnan V, Pelesikoti N, Tompkins E, Webb A (2014) Small islands. In: Barros VR, Field CB, Dokken DJ, Mastrandrea MD, Mach KJ, Bilir TE, Chatterjee M, Ebi KL, Estrada YO, Genova RC, Girma B, Kissel ES, Levy AN, MacCracken S, Mastrandrea PR, White LL (eds) Climate Change 2014: Impacts, Adaptation, and Vulnerability. Part B: Regional aspects. Contribution of Working Group II to the Fifth Assessment Report of the Intergovernmental Panel on Climate Change. Cambridge University Press, Cambridge, United Kingdom and New York, pp 1613-1654

Olefeldt D, Goswami S, Grosse G, Hayes D, Hugelius G, Kuhry P, McGuire AD, Romanovsky VE, Sannel ABK, Schuur EAG, Turetsky MR (2016) Circumpolar distribution and carbon storage of thermokarst landscapes. Nature Communications. https://doi.org/ 10.1038/NCOMMS13043

Ontario Laws (2010) Far North Act 2010, S.O.2010, c. 18 https://www. ontario.ca/laws/statute/10f18 Accessed 15 Oct 2017

Open Space Institute and North Atlantic Conservation Cooperative (2016) Conserving nature in a changing climate, pp 1-114 http:// climatechange.lta.org/resilience-guide/ Accessed 27 Aug 2017

Page SE, Siegert F, Rieley JO, Boehm H-DV, Jaya A, Limin S (2002) The amount of carbon released from peat and forest fires in Indonesia during 1997. Nature 420:61-65. https://doi.org/10.1038/ nature 01131

Page SE, Rieley JO, Banks CJ (2011) Global and regional importance of the tropical peatland carbon pool. Global Change Biology 17:798 818

Pan Y, Birdsey RA, Fang J, Houghton R, Kauppi PE, Kurz WA, Phillips OL, Shvidenko A, Lewis SL, Canadell JG, Ciais P, Jackson RB, Pacala SW, McGuire AD, Piao S, Rautiainen A, Sitch S, Hayes D (2011) A large and persistent carbon sink in the world's forests. Science 333(6045):988-993

Pendleton L, Donato DC, Murray BC, Crooks S, Jenkins WA, Sifleet S, Craft C, Fourqurean JW, Kauffman JB, Marba N, Megonigal JP, Pidgeon E, Herr D, Gordon D, Baldera A (2012) Estimating global "blue carbon" emissions from conversion and degradation of vegetated coastal ecosystems. PLoS ONE 7(9):e43542. https://doi.org/ 10.1371/journal.pone.0043542

Perry JE, Atkinson RB (2009) York River tidal marshes. Journal of Coastal Research 57:43-52

Petrescu AL, Tuovinen J-P, Baldocchi DD, Desai AR, Roulet NT, Vesala T, Dolman AJ, Oechel WC, Marcolla B, Friborg T, Rinne J, Matthes JH, Merbold L, Meijide A, Kiely G, Sottocornola M, Sachs T, Zona D, Varlagin A, Lai DY-F, Veenendaal E, Parmentier F-JW, Skiba U, Lund M, Hensen A, van Huissteden J, Flanagan LB, Shurpali NJ, Grünwald N, Humphreys ER, Jackowicz-Korczyński M, Aurela MA, Laurila T, Grüning C, Corradi CAR, Schrier-Uijl AP, 
Christensen TR, Tamstorf MP, Mastepanov M, Martikainen PJ, Verma S, Bernhofer BC, Cescatti A (2015) The uncertain climate footprint of wetlands under human pressure. PNAS 112(15):4594 4599. https://doi.org/10.1073/pnas.1416267112

Pittock J (2013) Lessons from adaptation to sustain freshwater environments in the Murray-Darling Basin, Australia. Wiley Interdisciplinary Reviews: Climate change 4:429-238

Pittock J, Finlayson CM, Gardner A, McKay C (2010) Changing character: the Ramsar Convention on Wetlands and climate change in the Murray-Darling Basin, Australia. Environmental and Planning Law Journal 27:401-442

Poff NL, Brinson MM, Day JW Jr (2002) Aquatic ecosystems and global climate change. Potential impacts on inland freshwater and coastal wetland ecosystems in the United States. Pew Charitable Trust, Philadelphia http://www.pewtrusts.org/ /media/legacy/ uploadedfiles/wwwpewtrustsorg/reports/protecting_ocean_life/ envclimateaquaticecosystemspdf.pdf

Ramsar COP11 (2012) Resolution XI.14 Climate change and wetlands: Implications for the Ramsar Convention on Wetlands http://archive. ramsar.org/cda/en/ramsar-documents-cops-cop11-cop11resolutions/main/ramsar/1-31-58-500\%5E25837_4000_0_ Accessed 15 Oct 2017

Ramsar COP12 (2015) Resolution XII.11 Peatlands, climate change and wise use: Implications for the Ramsar Convention Accessed 15 Oct 2017 http://www.ramsar.org/sites/default/files/documents/ library/cop 12 dr11 peatlands e.pdf Accessed 15 Oct 2017

REDD (2016) Reduced emissions from deforestation and forest degradation The REDD Desk http://theredddesk.org/what-redd Accessed 15 Oct 2017

Ricke KL, Caldeira K (2014) Maximum warming occurs about one decade after a carbon dioxide emission. Environmental Research Letters 9:124002. https://doi.org/10.1088/1748-9326/9/12/124002

Roser Renouf C, Maibach E, Leiserowitz A, Rosenthal S (2016) Global warming's six Americas and the election, 2016. Yale University and George Mason University New Haven, CT. Yale Program on Climate Change Communication

Sanderson BM, O'Neill BC, Tebaldi C (2016) What would it take to achieve the Paris temperature targets? Geophysical Research Letters 43:7133-7142. https://doi.org/10.1002/2016GL069563

Sannel ABK, Kuhry P (2008) Radiocarbon dating of peat profiles from the subarctic ecoclimatic region, west-central Canada. PANGAEA. https://doi.org/10.1594/PANGEA.786457

Schuur EAG, McGuire AD, Grosse G, Harden J, Hayes DJ, Hugelius H, Koven CD, Kuhry P, Lawrence DM, Natali SM, Olefeldt D, Romanovsky VE, Schädel C, Turetsky M, Treat C, Vonk J (2015) Climate change and the permafrost carbon feedback. Nature 520: 171-179. https://doi.org/10.1038/nature1433

Scientists' letters on EU Forest Biomass (2018) http://www.ase.tufts.edu/ gdae/Pubs/climate/LetterFromScientistsToEuParliament ForestBiomass_January_2018.pdf;

Shaw J, Ceman J (1999) Salt-marsh aggradation in response to lateHolocene sea-level rise at Amherst Point, Nova Scotia, Canada. The Holocene 9(4):439-451

Shepard CC, Crain CM, Beck MW (2011) The protective role of coastal marshes: A systematic review and meta-analysis. PLoS ONE 6(11): e27374. https://doi.org/10.1371/journal.pone.0027374

Shindell DT, Walter BP, Faluvegi G (2004) Impacts of climate change on methane emissions from wetlands. Geophysical Research Letters 31(21):L21202

Solomon S, Plattnerb G-K, Knuttic R, Friedlingstein P (2009) Irreversible climate change due to carbon dioxide emissions. PNAS 106(6): 61704-61709

Souter NJ, Cunningham S, Little S, Wallace T, McCarthy B, Henderson M (2010) Evaluation of a visual assessment method for tree condition of eucalypt floodplain forests. Ecological Management and Restoration 11:210-214
Souter NJ, Wallace T, Walter M, Watts R (2014) Raising river level to improve the condition of a semi-arid floodplain forest. Ecohydrology 7:334-344

SPREP (2017) Strategic plan 2017-2026. Secretariat of the Pacific Regional Environment Programme. Apia, Samoa $28 \mathrm{p}$

Strain MA, van Belzen J, Comandini P, Wong J, Bouma TJ, Airoldi L (2017) The role of changing climate in driving the shift from perennial grasses to annual succulents in a Mediterranean saltmarsh. Journal of Ecology 105:13741385

Sutter LS, Perry JE, Chambers RM (2014) Tidal freshwater marsh plant responses to low level salinity increases. Wetlands 34:167-175

Sutter LA, Chambers RM, Perry JE (2015) Seawater intrusion mediates species transition in low salinity, tidal marsh vegetation. Aquatic Botany 122:32-39

Sutton-Grier AE, Moore A (2016) Leveraging carbon services of coastal ecosystems for habitat protection and restoration. Coastal Management 44(3):259-277

Sutton-Grier AE, Bamford H, Wowk K (2015) Future of our coasts: the potential for natural and hybrid infrastructure to enhance the resilience of our coastal communities, economies and ecosystem. Environmental Science \& Policy 51:137-148

Sutton-Grier AE, Brody C, Herr D, Kairo J, Kunz M, Lopez Garcia E, Rosette M, Wylie L (2018) National policy opportunities to support blue carbon conservation. Chapter 17. In: Windham-Myers L, Crooks S, Troxler TG (eds) A blue carbon primer: The state of coastal wetland carbon science, practice and policy. CRC Press. ISBN 13:9781498769099. pp 352

The Nature Conservancy (2017) Available via http://maps.tnc.org/ resilientland/ Accessed 27 Aug 2017

Thomas CR, Blum LK (2010) Importance of the fiddler crab Uca pugnax to salt marsh soil organic matter accumulation. Marine Ecology Progress Series 414:167-177. https://doi.org/10.3354/meps08708

Tockner K, Stanford JA (2002) Riverine flood plains: Present state and future trends. Environmental Conservation 29:308-330

Torio D, Chmura GL (2013) Assessing coastal squeeze of tidal wetlands. Journal of Coastal Research 29(5):1049-1061. https://doi.org/10. 2112/JCOASTRES-D-12-00162.1

Trenberth KE, Fasullo JT, Shepherd TG (2015) Attribution of climate extreme events. Nature Climate Change 5:725-730

Turetsky MR, Kotowska A, Bubier J, Dise NB, Crill P, Hornibrook ERC, Minkkinen K, Moore TR, Myers-Smith IH, Nykänen H, Olefeldt D, Rinne J, Saarnio S, Shurpali N, Tuittila E-S, Waddington JM, White JR, Wickland KP, Wilmking M (2014) A synthesis of methane emissions from 71 northern, temperate, and subtropical wetlands. Global Change Biology 20:2183-2197. https://doi.org/10.1111/ gcb. 12580

UNFCCC (1992) United Nations Framework Convention on Climate Change. United Nations. 1992. FCCC/INFORMAL/84. GE.0562220 (E) $200705 \mathrm{http}: / /$ unfecc.int/essential_background/ convention/items/6036.php Accessed 15 Oct 2017

UNFCCC (2017) United Nations Framework Convention on Climate Change, Paris Agreement-Status of Ratification http://unfecc.int/ paris_agreement/items/9444.php Accessed 15 Oct 2017

USACE (2010) U.S. Army Corps of Engineers New England District compensatory mitigation guidance New England District, Regulatory Division, $\mathrm{p} 23$

USACE (2012) U.S. Army Corps of Engineers regional supplement to the Corps of Engineers wetland delineation manual: Northcentral and Northeast Region (Version 2.0). Wetlands Regulatory Assistance Program (Engineer Research and Development Center) pp 118-127

USEPA (2017) Gas emissions inventory of U.S. greenhouse gas emissions and sinks:1990-2015 https://www.epa.gov/ghgemissions/ inventory-us-greenhouse-gas-emissions-and-sinks-1990-2015 Accessed 15 Oct 2017

Waddington JM, Plach J, Cagampan J, Lucchese M, Strack M (2009) Reducing the carbon footprint of Canadian peat extraction and 
restoration. Ambio 38:194-200. https://doi.org/10.1579/00447447-38.4.194

Wilhelm LP, Morris PJ, Granath G, Waddington JM (2015) Assessment of an integrated peat-harvesting and reclamation method: Peatland-atmosphere carbon fluxes and vegetation recovery. Wetlands Ecol Manage 23(3):491-504. https://doi. org/10.1007/s11273-014-9399-6

Williams K, Ewel KC, Stumpf RP, Putz FE, Workman TW (1999) Sea -level rise and coastal forest retreat on the west coast of Florida, USA. Ecology 80:2045-2063

$\mathrm{Wu}$ J, Roulet NT (2014) Climate change reduces the capacity of northern peatlands to absorb the atmospheric carbon dioxide: The different responses of bogs and fens. Global Biogeochem Cycles 28:10051024. https://doi.org/10.1002/2014GB004845
Wylie L, Sutton-Grier AE, Moore A (2016) Keys to successful blue carbon projects: Lessons learned from global case studies. Marine Policy 65:76-84

Yale Program on Climate Communication (YPCCC) (2017) http:// climatecommunication.yale.edu. Accessed 10 Mar 2017

Zhang W, Zhu Y, Jiang J (2016) Effect of the Urbanization of Wetlands on Microclimate: A Case Study of Xixi Wetland, Hangzhou, China. Sustainability 8(885):1-13. https://doi.org/10.3390/su8090885

Zollitsch B, Christie J (2015) Status and trends report on state wetland programs in the United States. Association of State Wetland Managers. Maine, pp 57-58. https://www.aswm.org/pdf_lib/state_ summaries/status_and_trends_report_on_state_wetland_programs_ in_the_united_states_102015.pdf 